\title{
The Jurassic dinoflagellate cyst zonation of Subboreal Northwest Europe
}

\author{
Niels E. Poulsen and James B. Riding
}

With an appendix by Bjørn Buchardt: Oxygen isotope palaeotemperatures from the Jurassic in Northwest Europe

\begin{abstract}
The Jurassic dinoflagellate cyst zonation for the British-Danish area is revised and discussed in relation to palaeoenvironmental factors, in particular, eustatic changes and fluctuations in palaeotemperature. The stepwise evolution of dinoflagellate cyst assemblages as defined by inceptions and apparent extinctions was largely controlled by sea-level change, particularly during intervals with significant short-term eustatic fluctuations. During times characterised by less pronounced, or longer term, sea-level change, fluctuations in oceanic palaeotemperatures appear to have influenced dinoflagellate evolution. Differences in the ranges of certain taxa between Denmark and the United Kingdom may be partly related to differences in palaeotemperature.
\end{abstract}

Keywords: Subboreal Northwest Europe, Jurassic, dinoflagellate cyst zonation, palaeotemperatures and biotic provincialism, dinoflagellate palaeoecology

\footnotetext{
N.E.P., Geological Survey of Denmark and Greenland, Geocenter Copenhagen, Øster Voldgade 10, DK-1350 Copenhagen K, Denmark. E-mail: nep@geus.dk

J.B.R., British Geological Survey, Keyworth, Nottingham NG12 5GG, UK.

B.B., Geological Institute, University of Copenhagen, Geocenter Copenhagen, Øster Voldgade 10, DK-1350 Copenhagen K, Denmark.
}

This paper attempts a further integration and standardisation of the Jurassic dinoflagellate cyst zonation schemes established for the British and Danish areas (Fig. 1; Davey 1979, 1982; Woollam \& Riding 1983; Nøhr-Hansen 1986; Riding \& Thomas 1988, 1992; Poulsen 1991, 1992, 1994a; Koppelhus \& Nielsen 1994). In addition, the relationships between the zonation and palaeoecology are discussed, particularly with respect to the appearance and disappearance of species in relation to changes in sea level and palaeotemperature.

\section{Dinoflagellates}

Dinoflagellates are primarily motile single-celled algae. About half are autotrophic, phytosynthetic species, the reminder being non-photosynthetic consumers that ingest other organisms or particulate organic matter as predators, symbionts, parasites or decomposers. They have been a major component of marine phytoplankton since their diversification in the Late Triassic and became important in non-marine environments during the Early Cretaceous (Batten \& Lister 1988). The dinoflagellates have diversified into a wide range of ecological habitats and many of them are sensitive to environmental physical/chemical changes. The understanding of the response of extant dinoflagellates to environmental stress is not well-advanced. The prediction of environment, temperature, water depth and other parameters based on certain species, however, can be made with some accuracy (Wall et al. 1977; de Vernal et al. 1992). 


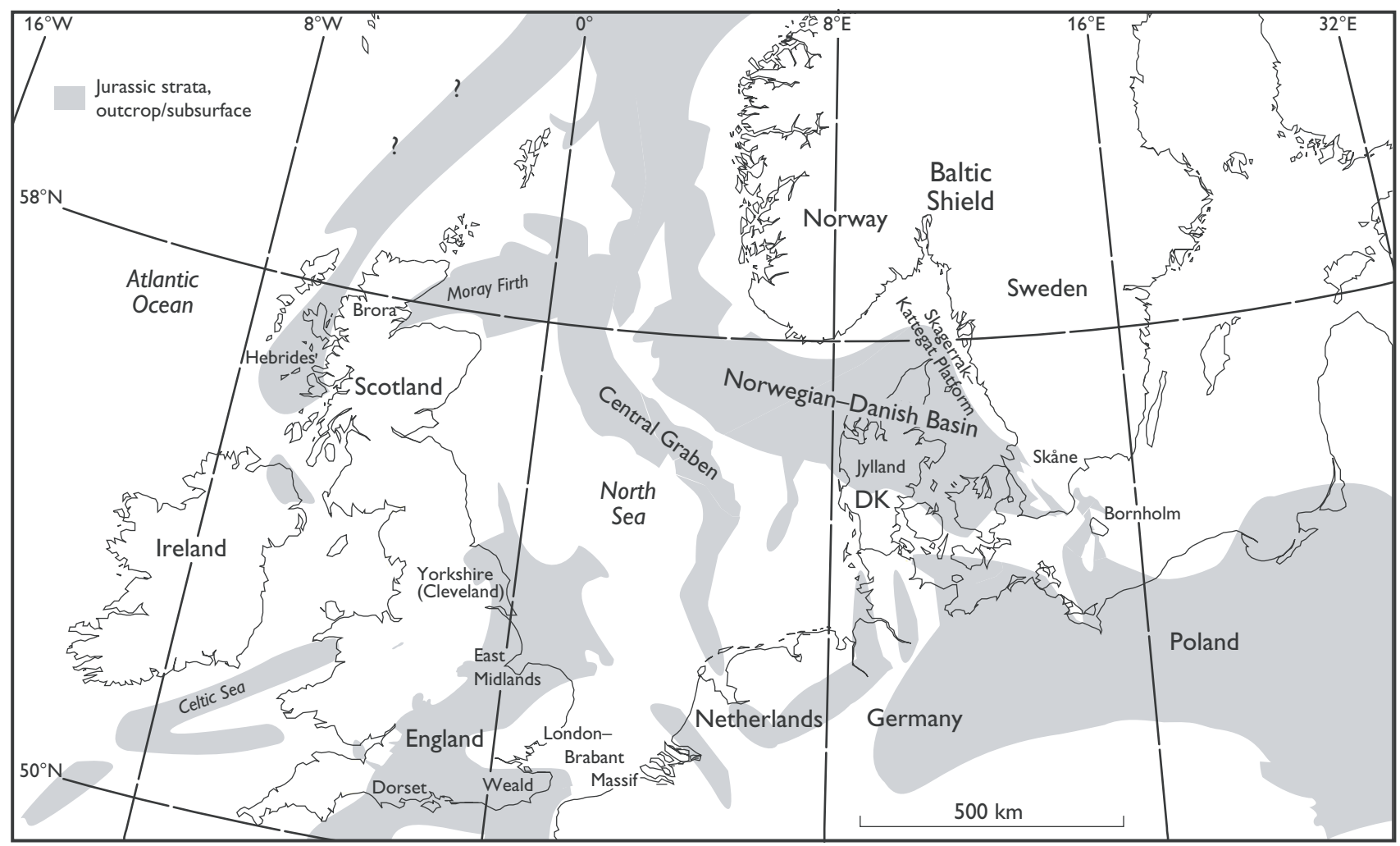

Fig. 1. Generalised distribution of Jurassic strata in Northwest Europe, both at outcrop and in the subsurface. Compiled from Brooks \& Chesher (1975), Czaplicka (1976), Michelsen (1978), Cope et al. (1980a, b), Guy-Ohlson (1986), Guy-Ohlson \& Norling (1988), Ziegler (1988), Andrews et al. (1990), Cameron et al. (1992), Hamblin et al. (1992), Rattey \& Hayward (1993), Stoker et al. (1993), Erlström et al. (1994), Hamann (1994), Koppelhus \& Nielsen (1994), Vejbæk \& Britze (1994) and Japsen et al. (2003, this volume). DK, Denmark.

Dinoflagellate cysts represent the non-motile dormant stage in the life cycle, resulting from sexual fusion (Evitt 1985); it is not known, however, whether encystment is related solely to sexual reproduction. Cysts are generally resistant to adverse conditions, whereas the motile thecate stage is quickly destroyed after death or encystment. Most resting cysts act as sedimentary particles and eventually sink to the sea floor, although many of them have adaptations to floating such as processes, an oil-rich cellular content or becoming entangled with floating debris (Sarjeant et al. 1987). The cyst distribution pattern is therefore not only dependent on ecological factors but also on sedimentary history.

Knowledge of the major factors controlling the distribution patterns of Jurassic dinoflagellate cysts cannot be obtained by analogy to modern taxa. However, detailed studies of pre-Neogene fossil dinoflagellates during the last 60 years have revealed distinctive distribution patterns of provincialism related to palaeosalinity, palaeotemperature and palaeowater-depth gradients.

\section{Geological framework}

During the latest Triassic and the earliest Jurassic, Denmark, the United Kingdom, and the North Sea Basin were part of the Subboreal Province (Fig. 2). The biogeographical affiliations of parts of this area changed, however, as the Tethyan Realm periodically expanded northwards, and occasionally retreated southwards. The main reasons for this are thought to be variations in seafloor spreading, the migration routes of faunas and floras or a combination of these factors. In general, the true Boreal Realm consisted of East Greenland (Jameson Land and adjacent areas), the Greenland Sea (northernmost Atlantic), the Boreal Sea, northern Siberia, the Arctic Islands and northern Canada (Enay 1972, 1980). The Norwegian-Danish Basin, the British Isles and the Central Graben are termed the Subboreal Province (Fig. 2). This province may be further divided into: (1) a southern part including southern England and the southern Central Graben, termed the Northwest European Subprovince, and (2) a northern part, or transitional area, i.e. the 
Norwegian-Danish Basin, northern United Kingdom and the northern Central Graben, referred to as the BorealSubboreal Subprovince (Fig. 2; Enay 1972, 1980).

Following deposition of the mainly continental Triassic succession, Jurassic sedimentation was largely marine and clastic-dominated. A number of major depocentres developed during the Jurassic in the Subboreal area, including the Celtic Sea, Weald, East Midlands, Cleveland, Moray Firth, Hebrides, Central Graben and DanishNorwegian basins (Fig. 1). Large parts of the North Sea region were affected by the Late Toarcian - Aalenian Central North Sea thermal or volcanic doming (Sellwood \& Hallam 1974; Whiteman et al. 1975; Eynon 1981; Ziegler 1988; Underhill \& Partington 1993). Following resumed subsidence and initial (Middle Jurassic) paralic/deltaic sedimentation, the North Sea region accumulated a thick marine succession dominated by the mud-rich deposits of the Kimmeridge Clay Formation and its correlatives.

During the Jurassic Period, representing some $70 \mathrm{Ma}$ of Earth history, the sedimentary successions attained (post-compaction) thicknesses in excess of $1600 \mathrm{~m}$ in onshore UK (Hallam 1992a), over $1200 \mathrm{~m}$ in the Danish Basin (the Danish part of the Norwegian-Danish Basin, see Fig. 1; Nielsen 2003, this volume) and over $4000 \mathrm{~m}$ in the deepest parts of the Danish Central Graben (Møller 1986; Sundsbø \& Megson 1993; Japsen et al. 2003 , this volume).

\section{Methods}

The ranges for the stratigraphical index dinoflagellate cyst species are based on those recorded in both the British

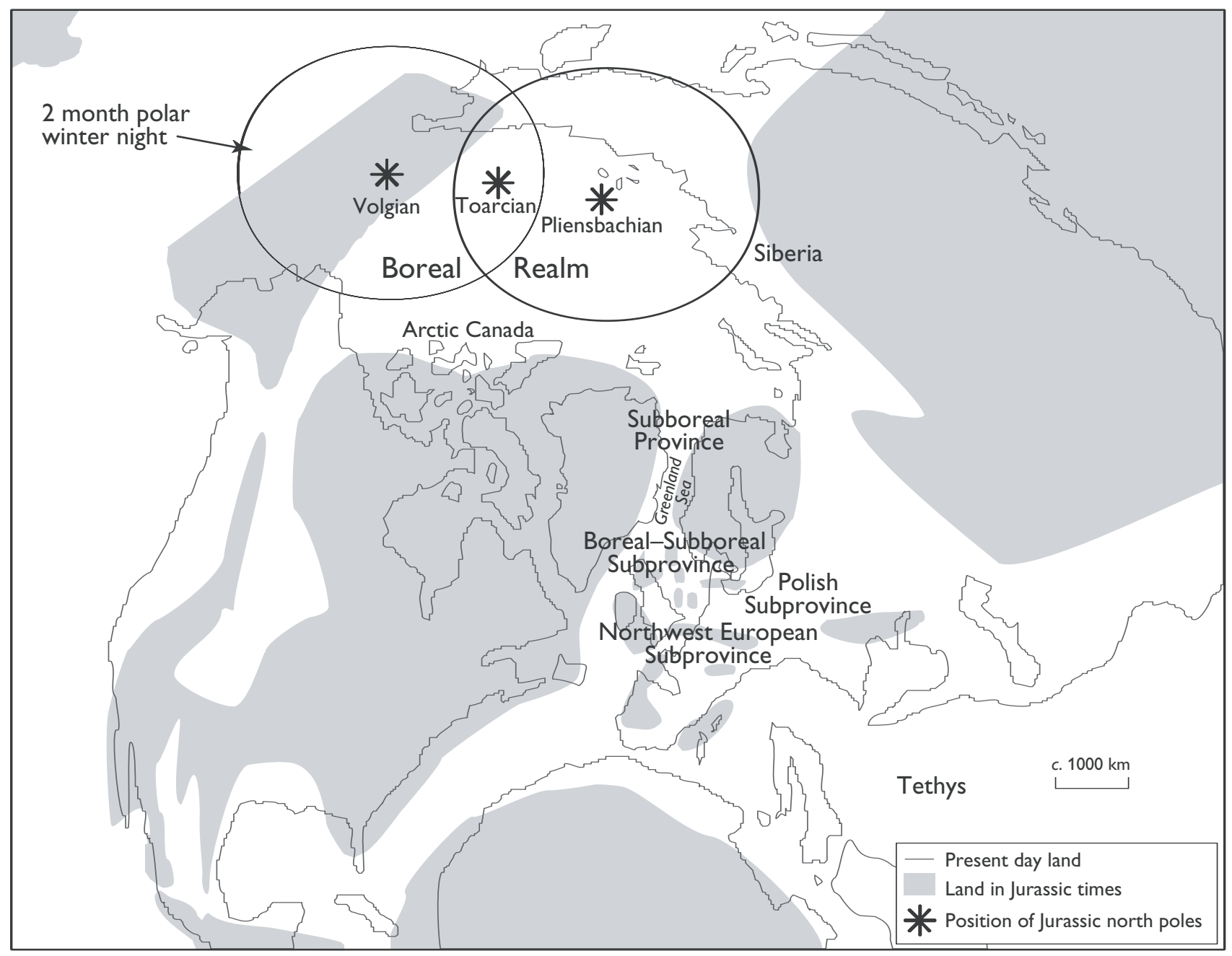

Fig. 2. Biogeographical realms, provinces and subprovinces (modified from Poulsen 1996, based on Enay 1972, 1980). The approximate geographical extent of the Pliensbachian and Volgian two-month polar night is indicated, assuming that precession was of the same order in the Mesozoic as at the present-day. 
and Danish areas. The zonation represents an idealised succession of bioevents, which takes into account factors such as local hiatuses, palaeoenvironmental/facies control on sediment distribution and ranges of taxa, natural variability and sampling problems. Range extension using graphical correlation (Shaw 1964; Edwards 1984, 1989) was not undertaken. Significant differences in ranges are not generally observed, although occasional exceptions have been recorded and are indicated on the composite range charts (see Figs 3-5). The Middle Jurassic of the Danish Central Graben and the Danish Basin consists mainly of coarse-grained, non-marine strata deposited during the Aalenian-Bathonian regressive event, or is represented by hiatuses. It contains few stratigraphic levels with marine intercalations and dinoflagellate cysts from this part of the Middle Jurassic are extremely rare (for further discussion, see Poulsen 1992, 1996). The dinoflagellate cyst ranges for the Middle Jurassic are therefore based on ranges determined from the United Kingdom.

Facies control may have influenced the dinoflagellate cyst assemblages, making them variable in composition inter-regionally. The principal aim here is to present a zonation for the Subboreal area that is tested against other faunal zonations, such as those for ammonites and ostracods, and in which apparent variations in ranges have been taken into account, thus giving the best overall regional correlations. As a result of variations in sample availability, inadequate data in certain intervals means that the exact correlation of dinoflagellate cyst zonal boundaries to ammonite zonal boundaries may be uncertain. In such cases, the boundaries are deemed to be coincident, although this methodology may introduce certain minor errors.

The ammonite zones are chronostratigraphical units (Wimbledon \& Cope 1978; Callomon 1984; Cox 1990; Page 2003, this volume) and are thus referred to by the species name alone, in Roman type (e.g. Tenuicostatum Zone). This is the convention followed by working groups of the International Subcommission on Jurassic Stratigraphy (ISJS) and the International Commission on Stratigraphy (ICS). The base of the Jurassic is taken at the inception of the ammonite genus Psiloceras, which marks the base of the Planorbis Zone as recommended by Warrington et al. (1994; for further discussion, see Page 2003, this volume).

The dinoflagellate cyst zones are indicated by the generic and specific names of the index taxon in italics, e.g. Dapcodinium priscum Zone. Only the taxa which are useful for identifying each zone or subzone are cited; accessory forms are consistently present but these are not usually biostratigraphically diagnostic.

\section{Stratigraphic palynology}

Davey \& Riley (1978) and Morbey \& Dunay (1978) presented a summary of knowledge of Upper Triassic and Jurassic dinoflagellate cyst biostratigraphy in Northwest Europe. Williams \& Bujak (1985) subsequently published an extensive synthesis of dinoflagellate cyst zonation schemes for the Triassic to Quaternary interval. Riding \& Thomas (1992) and Riding \& Ioannides (1996) outlined the history of study of Jurassic dinoflagellate cyst biostratigraphy. Poulsen (1991, 1992, 1993, 1994a, b, 1996, 1998) demonstrated the utility of the British Jurassic dinoflagellate cyst zonations of Woollam \& Riding (1983) and Riding \& Thomas (1992) in Denmark and Poland.

This paper attempts further emendation, integration and standardisation of Jurassic dinoflagellate cyst zonal schemes. The zonation presented herein (Table 1) is an integrated zonation for Denmark and the United Kingdom based on the zonations presented by Davey (1979, 1982), Woollam \& Riding (1983), Nøhr-Hansen (1986), Riding \& Thomas (1988, 1992) and Poulsen (1991, 1992, 1994b, 1996). The British and Danish zonations are in general identical, with the exception of certain new subzones and other emendations that resulted from simultaneous, independent revisions by Poulsen (1992) and Riding \& Thomas (1992); these differences are integrated and standardised here. Only the necessary emendations and other pertinent comments for unifying the British and Danish zonations are given below.

It should be noted that the Middle-Upper Jurassic dinoflagellate cyst zones have been recognised in Poland (Poulsen 1992, 1993, 1994a, 1996, 1998). These zones are also widely recorded in the Jurassic deposits in Europe and adjacent regions, for example in onshore United Kingdom (the Wessex, East Midlands, Cleveland, Hebrides and onshore Moray Firth basins), the Danish Basin and in the Danish sector of the North Sea Central Graben.

The zones have been named following biostratigraphical tradition and international stratigraphical guidelines and recommendations, with the zonal name related to an index species, for example, the Acanthaulax senta Zone. Following international rules, zonal names change to conform with any valid changes to the name of the index species (Hedberg 1976; Salvador 1994); for example, the Acanthaulax senta Zone of Woollam \& Riding (1983) became the Liesbergia scarburghensis Zone of Riding \& Thomas (1992) and is now the Trichodinium scarburghensis Zone. Further- 
Table 1. Jurassic dinoflagellate cyst zonation

\begin{tabular}{|c|c|c|}
\hline $\begin{array}{l}\text { Zonation } \\
\text { (this study) }\end{array}$ & Formal zonal name & Reference $^{\#}$ \\
\hline DSK2 & Endoscrinium pharo Subzone (or Gochteodinia villosa Zone, Subzone c) & $1(26)$ \\
\hline DSK1 & Rotospaheropsis thula Subzone (or Gochteodinia villosa Zone, Subzone b (pars)) & $19(26)$ \\
\hline DSJ39 & Gochteodinia villosa Zone, Subzone b (pars) & $9(6)$ \\
\hline DSJ38 & Exmontodinium expiratum Subzone (pars) or Gochteodinia villosa Zone, Subzone a & 169 \\
\hline DSJ37 & Dingodinium spinosum Zone & 1 \\
\hline DSJ36 & Dichadogonyaulax culmula Zone, Subzone b (pars) & 12569 \\
\hline DSJ35 & Dichadogonyaulax culmula Zone, Subzone a & 1256 \\
\hline DSJ34 & Glossodinium dimorphum Zone, Subzone e & 6 \\
\hline DSJ33 & Glossodinium dimorphum Zone, Subzone d & 6 \\
\hline DSJ32 & Glossodinium dimorphum Zone, Subzone c & 6 \\
\hline DSJ31 & Glossodinium dimorphum Zone, Subzone b & 6 \\
\hline DSJ30 & Glossodinium dimorphum Zone, Subzone a & 6 \\
\hline DSJ29 & Endoscrinium luridum Zone, Perisseiasphaeirdium pannosum Subzone & 5 \\
\hline DSJ28 & Endoscrinium luridum Zone, Stephanelytron scarburghense Subzone & 5 \\
\hline DSJ27 & Scriniodinium crystallinum Zone, Subzone d & 46 \\
\hline DSJ26 & Scriniodinium crystallinum Zone, Subzone c & 46 \\
\hline DSJ25 & Scriniodinium crystallinum Zone, Subzone b & 46 \\
\hline DSJ24 & Scriniodinium crystallinum Zone, Subzone a (pars) & $9(6)$ \\
\hline DSJ23 & Scriniodinium crystallinum Zone, Subzone a (pars) & $9(6)$ \\
\hline DSJ22 & Trichodinium scarburghense Zone, Subzone b & $9(2)$ \\
\hline DSJ21 & Trichodinium scarburghense Zone, Subzone a & $9(2)$ \\
\hline DSJ20 & Wanaea fimbriata Zone & 26 \\
\hline DSJ19 & Wanaea thysanota Zone & 26 \\
\hline DSJ18 & Ctenidodinium continuum Zone & $6(2)$ \\
\hline DSJ17 & Ctenidodinium sellwoodii Zone, Subzone c & $6(2)$ \\
\hline DSJ16 & Ctenidodinium sellwoodii Zone, Subzone b & $6(2)$ \\
\hline DSJ15 & Ctenidodinium sellwoodii Zone, Subzone a & $6(2)$ \\
\hline DSJ14 & Cribroperidinium crispum Zone, Subzone b & $69(2)$ \\
\hline DSJ13 & Cribroperidinium crispum Zone, Subzone a & $69(2)$ \\
\hline DSJ12 & Nannoceratopsis gracilis Zone, Subzone e & 6 \\
\hline DSJ11 & Nannoceratopsis gracilis Zone, Subzone d & 6 \\
\hline DSJ10 & Parvocysta nasuta Zone (stat. nov.) (pars), (Nannoceratopsis gracilis Zone, Subzone c) & $9(56)$ \\
\hline DSJ9 & Parvocysta nasuta Zone (stat. nov.) (pars), (Nannoceratopsis gracilis Zone, Subzone b) & $9(56)$ \\
\hline DSJ8 & Mancodinium semitabulatum Zone (emend. nov.) & $9(256)$ \\
\hline DSJ7 & Luehndea spinosa Zone, Subzone b & 6 \\
\hline DSJ6 & Luehndea spinosa Zone, Subzone a, or Luehndea spinosa Zone, Subzone b & 6 or 8 \\
\hline DSJ5 & Nannoceratopsis senex Zone (new), (Luehndea spinosa Zone, Subzone a) & $9(8)$ \\
\hline DSJ4 & Mendicodinium reticulatum Zone, (Liasidinium variabile Zone, Subzone b) & $7(2)$ \\
\hline DSJ3 & Liasidinium variabile Zone, Subzone a & 2 \\
\hline DSJ2* & Dapcodinium priscum Zone, Subzone b & 25 \\
\hline $\mathrm{DSJ} 1 *$ & Dapcodinium priscum Zone, Subzone a & 25 \\
\hline DSTr & Rhaetigonyaulax rhaetica Zone & 2 \\
\hline
\end{tabular}

\# References:

1: Davey $(1978,1982)$

2: Woollam \& Riding (1983)

7: Koppelhus \& Nielsen (1994)

3: Nøhr-Hansen (1986)

8: Poulsen (1994a)

4: Riding \& Thomas (1988)

9: this study

5: Poulsen $(1991,1992)$

6: Riding \& Thomas (1992)

* Note that in the United Kingdom it is not possible to separate these two zones, hence they are termed Zone DSJ1-2 
more, Riding \& Thomas (1992) used a three-letter abbreviation for their Jurassic dinoflagellate cyst zones (e.g. Lsc for the Liesbergia scarburghensis Zone).

Calcareous nannoplankton, foraminiferal and other biozones are often denoted by an alphanumeric code in which the first letter indicates the respective fossil group, for example $\mathrm{N}$ for (calcareous) nannoplankton, and the second letter indicates a Period or Epoch $-\mathrm{P}$ for Palaeogene and $\mathrm{N}$ for Neogene. Each zone is thus enumerated NP24, NP25, NN1, NN2, NN3 etc. This method results in abbreviations (e.g. NN9) which are easier and more convenient to use, especially for nonpalaeontologists; this methodology is adopted here.

The dinoflagellate cyst zones evaluated in this study are thus given a similar code e.g. Zone DSJ13, (D for dinoflagellate cysts, $\mathrm{S}$ is added to emphasise that it is a Subboreal zonation, Tr for Triassic, J for Jurassic and $\mathrm{K}$ for Cretaceous, see Table 1). The Jurassic and Cretaceous are numbered, whereas only one zone is recognised for the Triassic. As almost every Jurassic dinoflagellate cyst zone is divided into subzones, the subzones are generally taken as the basic numbered biounits in this study. The zonation is, where possible, defined both by species with first occurrences and last appearances coincident with the zonal boundaries.

\section{Dinoflagellate cyst zonation}

The zonation presented below is an attempt to further refine the work of R.J. Davey, H. Nøhr-Hansen, N.E. Poulsen, J.B. Riding, J.E. Thomas, R. Woollam and others, and to integrate and standardise the Jurassic dinoflagellate cyst zonation scheme (Table 1). Accounts of the ranges of the index species can be found in Raynaud (1978), Davey (1979, 1982), Fisher \& Riley (1980), Woollam (1980), Riding (1982, 1984a, b, 1987), Riley \& Fenton (1982), Woollam \& Riding (1983), Riding et al. (1985), Riding \& Sarjeant (1985), Nøhr-Hansen (1986), Riding \& Thomas (1988, 1992, 1997), Riley et al. (1989), Poulsen (1991, 1992, 1993, 1996), Riding et al. (1991), Partington et al. (1993) and J.B. Riding, J.E. Thomas and I.P. Wilkinson (in: Richards et al. 1993).

\section{Triassic zonation}

\section{DSTr; Upper Triassic (Rhaetian)}

A single zone, DSTr, is established for the Upper Triassic (Rhaetian). The DSTr Zone corresponds to the Rhaeto- gonyaulax rhaetica Zone of Woollam \& Riding (1983), which is based on the common/abundant presence of Rhaetogonyaulax rhaetica (Fig. 3). This zone may locally be further divided into two or three new zones defined on the abundance, presence and/or absence of Sverdrupiella spp., Heibergella spp., Suessia spp. and Rhaetogonyaulax rhaetica. These relatively high diversity associations are most likely to occur in the peripheral regions of the Subboreal Province.

\section{Jurassic - lowermost Cretaceous zonation}

\section{DSJ1, DSJ2; uppermost Triassic - Lower Sinemurian} (Turneri Zone)

The DSJ1 and DSJ2 Zones are equivalent to the Dapcodinium priscum Zone of Woollam \& Riding (1983); the lower part of the DSJ1 Zone spans the Triassic-Jurassic boundary. Subzones a and b of the Dapcodinium priscum Zone are herein named the DSJ1 and DSJ2 Zones, respectively (Fig. 3). In Denmark, the DSJ1 Zone is coincident with the range of D. priscum in the uppermost Triassic and Lower Sinemurian; the index species is absent in the DSJ2 Zone. The range top of the index species, D. priscum, appears to become younger in more southerly areas relative to the northern Subboreal Province. As stated above, in the Danish Embayment the $D$. priscum Zone may be subdivided into two subzones, the upper of which is characterised by the absence of $D$. priscum. In the United Kingdom, D. priscum has been recorded in the Lower Sinemurian Turneri Zone (Riding 1984a), thereby negating the bipartite subzonal division of the D. priscum Zone in the United Kingdom initially advocated by Woollam \& Riding (1983). In the United Kingdom, the zones established here are termed the DSJ1-2 Zones to indicate that the D. priscum Zone is not subdivided. Further south, in Portugal, Davies (1985) recorded D. priscum from the Lower Pliensbachian.

\section{DSJ3; Upper Sinemurian}

\section{(Obtusum-Raricostatum Zones)}

This zone corresponds to the Liasidium variabile Zone, Subzone a of Woollam \& Riding (1983) and Riding \& Thomas (1992) and coincides with the total range of the index species (Fig. 3). 
DSJ4; Lower Pliensbachian

(Jamesoni - Davoei (pars) Zones)

The DSJ 4 Zone is characterised by the presence of Mendicodinium reticulatum or is marked by the absence of dinoflagellate cysts. Koppelhus \& Nielsen (1994) erected the equivalent Lower Pliensbachian Mendicodinium reticulatum Zone below the Luehndea spinosa Zone. The Mendicodinium reticulatum Zone is equivalent to Subzone b of the Liasidium variabile Zone of Woollam \& Riding (1983) and Riding \& Thomas (1992).

\section{DSJ5-7; Lower Pliensbachian - Lower Toarcian (Davoei (pars) - Tenuicostatum Zones)}

The Upper Pliensbachian Luehndea spinosa Zone of Woollam \& Riding (1983) was expanded into the lowermost Toarcian and subdivided into Subzones a and b by Riding \& Thomas (1992) and Poulsen (1994a). However, the subzones were defined differently by these authors and Subzone b of Poulsen (1994a) corresponds to Subzone a of Riding \& Thomas (1992). A three-fold division of the Luehndea spinosa Zone is thus proposed below.

DSJ5; Lower Pliensbachian (Davoei Zone (pars)) The DSJ5 Zone corresponds to the Luehndea spinosa Zone, Subzone a of Poulsen (1994b) and is here formally renamed the Nannoceratopsis senex Zone. The zone is defined in Poulsen (1994a) as the interval from the inception of $N$. senex to the first occurrences of L. spinosa and other species of Nannoceratopsis (Fig. 3).

DSJ6; Pliensbachian (Margaritatus, Spinatum Zones) This interval corresponds to the Luehndea spinosa Zone, Subzone a of Riding \& Thomas (1992) and Subzone b of Poulsen (1994a). The zone is defined as Subzone a in Riding \& Thomas (1992) and additional species are used to define the base of Subzone $b$ of Poulsen (1994b). It is therefore defined herein as the interval from the inceptions of L. spinosa, Mancodinium semitabulatum, Maturodinium inornatum, Nannoceratopsis gracilis, $N$. raunsgaardii, $N$. ridingii, $N$. triceras and Valvaeodinium armatum to the range tops of M. inornatum and V. armatum.

DSJ7; lowermost Toarcian (Tenuicostatum Zone) The DSJ7 Zone corresponds to the Luehndea spinosa Zone, Subzone b of Riding \& Thomas (1992) and was defined as the interval from the apparent extinction of Maturodinium inornatum and Valvaeodinium armatum, to the range top of Luehndea spinosa (Fig. 3).

\section{DSJ8; Lower Toarcian}

(Falciferum, Bifrons (pars) Zones)

The DSJ8 Zone broadly corresponds to the Mancodinium semitabulatum Subzone of Poulsen (1992) and Subzone a of the Nannoceratopsis gracilis Zone of Riding \& Thomas (1992; Table 1). The DSJ8 Zone also forms part of the Mancodinium semitabulatum Zone, Subzone a of Woollam \& Riding (1983).

\section{DSJ9-10; Lower Toarcian - lowermost Aalenian (Bifrons (pars) - Opalinum Zones)}

The Parvocysta nasuta range Subzone of Poulsen (1992) is herein raised in status to that of a Zone and is formally divided into two Subzones, a and b, corresponding to Subzones b and c, respectively, of the Nannoceratopsis gracilis Zone of Riding \& Thomas (1992). The inceptions of Nannoceratopsis dictyambonis, Phallocysta elongata, and Susadinium scrofoides define the boundary between Subzones a and b, which are equivalent to the DSJ9 and DSJ10 Zones, respectively (Fig. 3). The stratigraphically important species Nannoceratopsis ambonis, Nannoceratopsis dictyambonis, Scriniocassis priscus and Scriniocassis weberi are not found in the Danish Basin, although they are characteristic elements both in the United Kingdom (Woollam \& Riding 1983; Riding 1987) and Germany (Prauss 1989).

\section{DSJ11, DSJ12; Aalenian - Lower Bajocian (Murchisonae-Sauzei Zones)}

The DSJ11 and DSJ12 Zones correspond precisely to Subzones d and e, respectively, of the Nannoceratopsis gracilis Zone of Riding \& Thomas (1992; Fig. 4, Table 1).

\section{DSJ13, DSJ14; Lower-Upper Bajocian (Humphriesianum-Parkinsoni Zones)}

The DSJ13 and DSJ14 Zones are equivalent to the Acanthaulax crispa Zone of Riding \& Thomas (1992). The Acanthaulax crispa Zone of Riding \& Thomas (1992) 


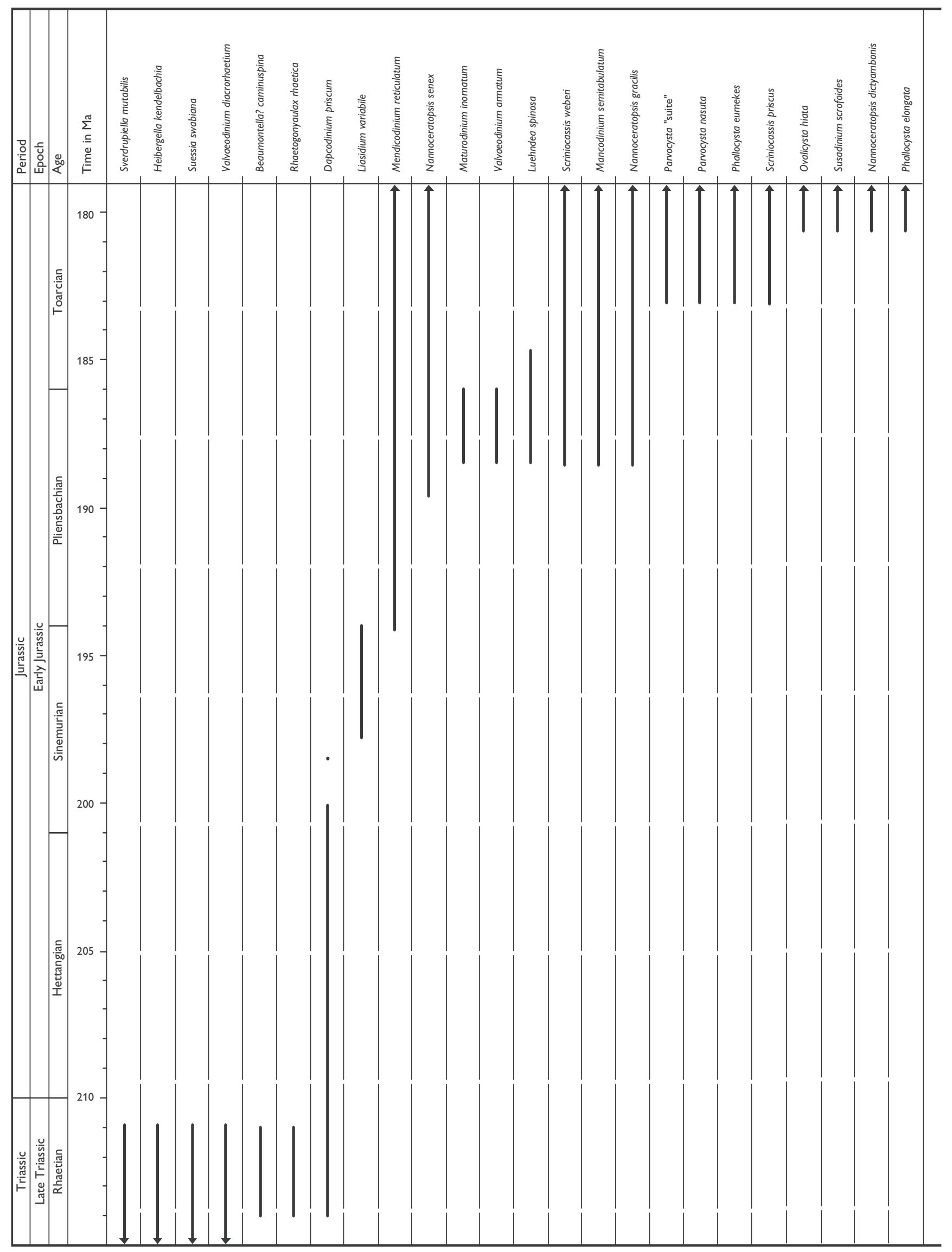




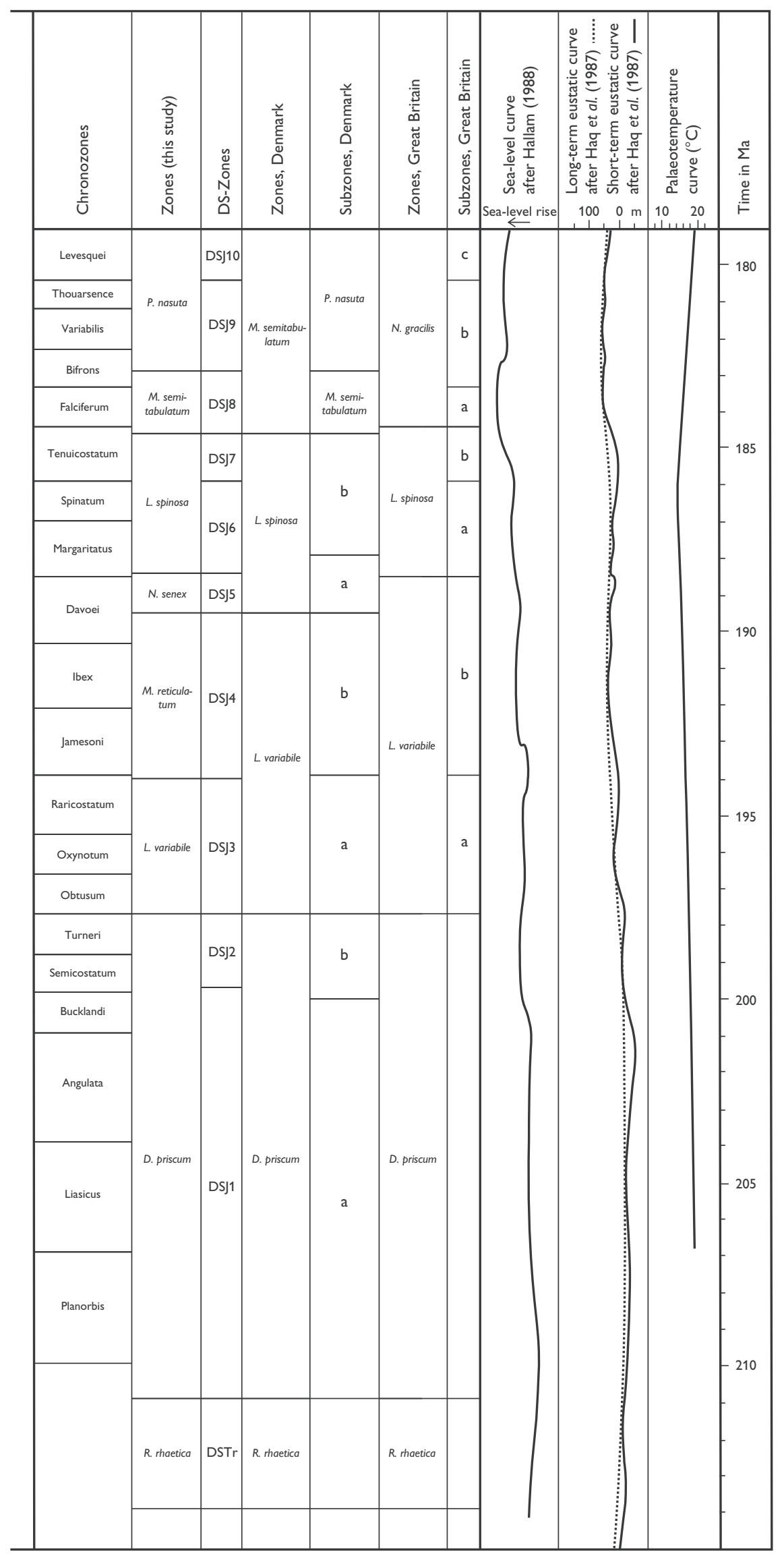

Fig. 3. Composite range chart for the key marker dinoflagellate cyst species in the Lower Jurassic of the Subboreal region. In Figs 3-5, the eustatic sea-level curves are from Haq et al. (1987) and Hallam (1988), the palaeotemperature curve is courtesy of B. Buchardt (Appendix 1) and the time-scale is from Haq et al. (1987). Note that Danish Jurassic ammonite recovery is sporadic and that only certain chronostratigraphic zones can be identified using macrofossils (Poulsen 1996). 


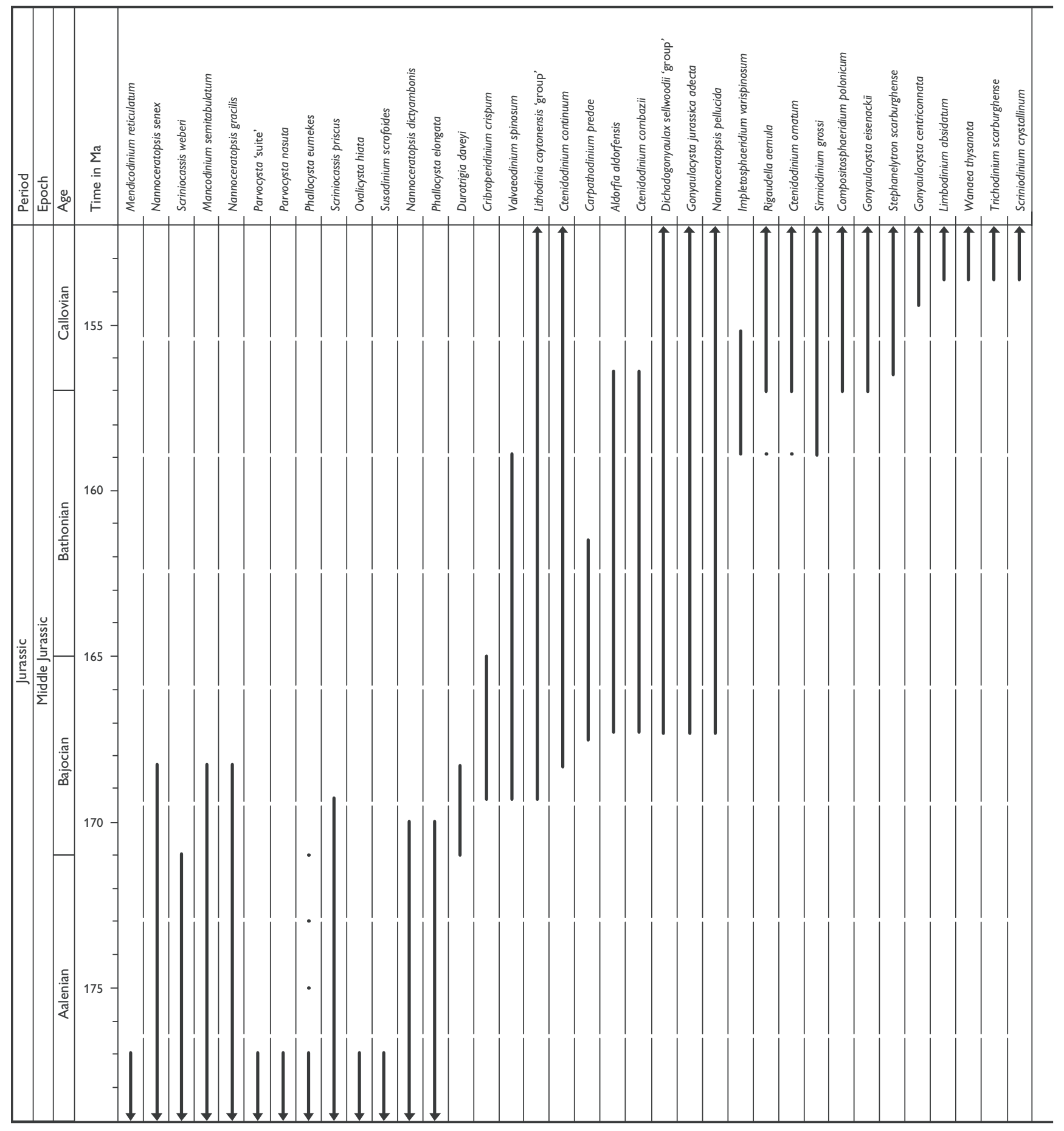

is renamed the Cribroperidinium crispum Zone to accommodate the change in name of the index species (Hedberg 1976; Salvador 1994). The Acanthaulax crispa (Cribroperidinium crispum) Zone was divided into Subzones a and b by Riding \& Thomas (1992) and the DSJ13 and DSJ14 Zones correspond precisely to Subzones a and b, respectively.

\section{DSJ15-18; Bathonian - Middle Callovian (Zigzag-Coronatum Zones)}

Zones DSJ15, DSJ16 and DSJ17 correspond respectively to Subzones a, b and c of the Ctenidodinium sellwoodii Zone of Riding \& Thomas (1992; Fig. 4). The latter biozone largely equates to the Ctenidodinium combazii- 


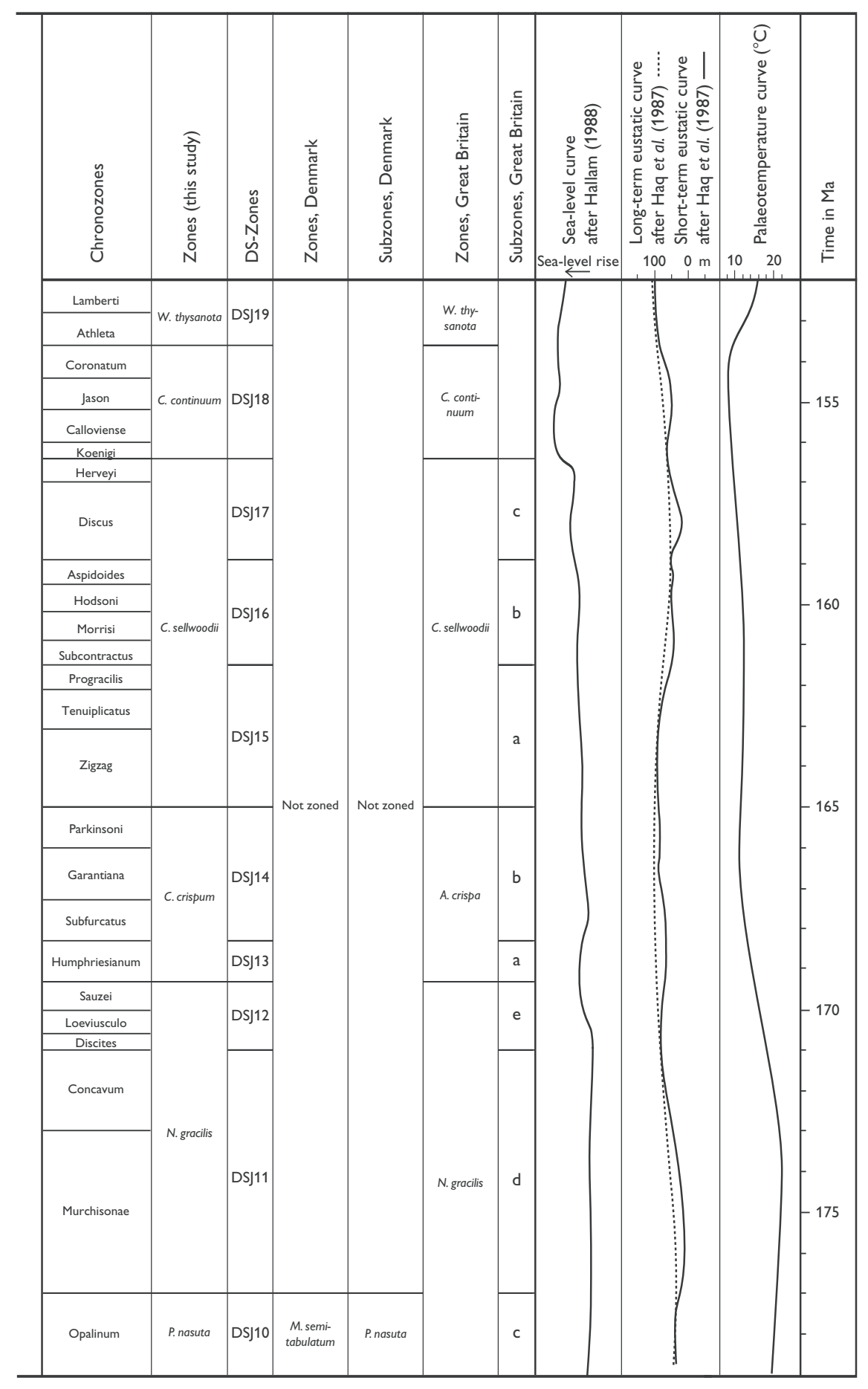

Fig. 4. Composite range chart for the key marker dinoflagellate cyst species in the Middle Jurassic of the Subboreal region.

Ctenidodinium sellwoodii Zone of Woollam \& Riding (1983). The DSJ18 Zone is coeval with the Ctenidodinium continuum Zone of Riding \& Thomas (1992), which is broadly coincident with the Ctenidodinium ornatum-Ctenidodinium continuum Zone of Woollam \& Riding (1983).
DSJ19; Upper Callovian (Athleta, Lamberti Zones)

The DSJ19 Zone corresponds to the Wanaea thysanota Zone of Riding \& Thomas (1992), formerly the Wanaea thysanota Zone (Subzones a and b) of Woollam \& Riding (1983). The subdivision of the Wanaea thysanota Zone, based on the range base of Trichodinium scar- 
burghensis, was discontinued by Riding \& Thomas (1992).

\section{DSJ20; lowermost Oxfordian (Mariae Zone)}

The DSJ20 Zone equates to the Wanaea fimbriata Zone of Woollam \& Riding (1983) and Riding \& Thomas (1992). The definition of the upper boundary of the DSJ20 Zone is given below, in the text pertaining to the DSJ21 and DSJ22 Zones.

\section{DSJ21, DSJ22; Lower-Middle Oxfordian (Cordatum, Densiplicatum Zones)}

The name of the Liesbergia scarburghensis Zone of Riding \& Thomas (1992), originally the Acanthaulax senta Zone of Woollam \& Riding (1983), is changed to the Trichodinium scarburghensis Zone due to the name change of the index species (Hedberg 1976; Salvador 1994). The inception of forms belonging to the Systematophora areolata group was used to redefine the lower boundary of this zone by Riding \& Thomas (1992). The distribution of the Systematophora areolata group in the United Kingdom and the Danish Embayment appears to be palaeoenvironmentally controlled (Poulsen 1992, 1996; Riding \& Thomas 1992) and this group is therefore excluded from the revised definition, given below.

DSJ21; Lower Oxfordian (Cordatum Zone)

The base of this zone is defined by the range base of Leptodinium subtile (Fig. 5). The top of the DSJ21 Zone is defined by the range tops of Gonyaulacysta centriconnata, Limbodinium absidatum and Wanaea thysanota and the inception of Endoscrinium luridum. The age of the zone corresponds to the Cordatum Zone; Poulsen (1996) presented a detailed discussion of the dinoflagellate cyst zonations at the Middle-Upper Jurassic boundary.

DSJ22; Middle Oxfordian (Densiplicatum Zone)

The base of this zone is defined by the last occurrences of Gonyaulacysta centriconnata, Limbodinium absidatum and Wanaea thysanota and the range base of Endoscrinium luridum (Fig. 5). The top of Zone DSJ22 is defined by the range top of the Lithodinia caytonensis group, and the inceptions of Glossodinium dimorphum and Scriniodinium inritibile.
DS|23-27; Middle Oxfordian - lowermost Kimmeridgian (Tenuiserratum-Baylei Zones)

The Gonyaulacysta jurassica - Scriniodinium crystallinum dinoflagellate cyst zone of Woollam \& Riding (1983) is herein divided into five DSJ Zones. The zone and its three subzones were defined by Woollam \& Riding (1983) and emended by Riding \& Thomas (1988, 1992); the upper boundary of the zone was emended by Poulsen (1991). By introducing further subdivision, a redefinition of the zone and its constituent subzones is therefore required here (Fig. 5).

DSJ23; Middle Oxfordian (Tenuiserratum Zone)

The base of Zone DSJ23 is defined by the range top of the Lithodinia caytonensis group and the inceptions of Glossodinium dimorphum and Scriniodinium inritibile. The top of Zone DSJ23 is defined by the last occurrences of Rigaudella aemula and Trichodinium scarburghensis. Zone DSJ23 is coeval with the Lsc (c) Subzone of Riding \& Thomas (1992).

DSJ24; Upper Oxfordian (Glosense Zone)

The base of the DSJ24 Zone is defined by the apparent extinctions of Rigaudella aemula and Trichodinium scarburghensis; the top is defined by the range top of Compositosphaeridium polonicum. It is equivalent to the Scr (a) Subzone of Riding \& Thomas (1992).

DSJ25; Upper Oxfordian (Serratum, Regulare Zones) The base of the DSJ25 Zone is defined by the range top of Compositosphaeridium polonicum. The top is defined by the last occurrence of Gonyaulacysta jurassica subsp. adecta and the first appearances of Dingodinium tuberosum and Occisucysta balia. The DSJ25 Zone is equivalent to the Scr (b) Subzone of Riding \& Thomas (1992).

\section{DSJ26; Upper Oxfordian (Rosenkrantzi Zone)}

The base of the DSJ26 Zone is defined by the range top of Gonyaulacysta jurassica subsp. adecta and the first appearances of Dingodinium tuberosum and Occisucysta balia. The top of the zone is defined by the last occurrence of Ctenidodinium ornatum and the inception of Senoniasphaera jurassica. The DSJ26 Zone equates to the Scr (c) Subzone of Riding \& Thomas (1992). 
DSJ27; Lower Kimmeridgian (Baylei Zone)

The base of the DSJ27 Zone is defined by the range top of Ctenidodinium ornatum and the inception of Senoniasphaera jurassica. The top of the zone is defined by the last occurrences of Gonyaulacysta eisenackii, Nannoceratopsis pellucida and Scriniodinium crystallinum, and the first appearances of Cribroperidinium? longicorne and Oligosphaeridium patulum. The DSJ27 Zone equates to the Scr (d) Subzone of Riding \& Thomas (1992).

DSJ28, DSJ29; Kimmeridgian

(Cymodoce-Autissiodorensis Zones)

A bipartite subdivision of the Endoscrinium luridum Zone (formerly the Scriniodinium luridum Zone) of Woollam \& Riding (1983) was introduced by NøhrHansen (1986); the zone was subsequently expanded and emended by Riding \& Thomas (1988) and Poulsen (1991). The definition of the lower boundary of the Endoscrinium luridum Zone of Riding \& Thomas (1992), and thus the DSJ28 Zone, is here extended to include the last occurrence of Gonyaulacysta eisenackii. The definitions of the top of Zone DSJ28 (or the Stephanelytron scarburghense Subzone of Nøhr-Hansen 1986) and the base and top of Zone DSJ29 (or the Perisseiasphaeridium pannosum Subzone) follow Poulsen (1991). The definition of the top of Zone DSJ29 is emended to include the first appearances of Egmontodinium polyplacophorum and Systematophora daveyi (Fig. 5).

\section{DSJ30-34; Lower-Middle Volgian (Elegans-Fittoni Zones)}

The DSJ30-34 Zones correspond respectively to Subzones a to e of the Glossodinium dimorphum (Gdi) Zone of Riding \& Thomas (1992). These units are coeval with Subzones b and c of the Glossodinium dimorphum - Dingodinium tuberosum Zone of Woollam \& Riding (1983).

\section{DSJ35-37; Middle Volgian}

$$
\text { (Albani-Anguiformis Zones) }
$$

The DSJ35, DSJ36 and DSJ37 Zones are the equivalent of the Dichadogonyaulax culmula and Dingodinium? spinosum zones of Davey (1979). The latter are also equivalent to the Dichadogonyaulax? pannea Zone of Riding \& Thomas (1992; formerly the Ctenidodinium culmulum-Ctenidodinium panneum Zone of Woollam \& Riding 1983). In this zonation for the entire BritishDanish area, the subdivision of the Dichadogonyaulax culmula and Dingodinium? spinosum zones of Davey (1979, 1982) is used, and the Dichadogonyaulax culmula Zone is further subdivided into two zones (DSJ35 and DSJ36; Fig. 5). It should be noted that the boundary between the Dichadogonyaulax culmula Zone (DSJ36) and the Dingodinium? spinosum Zone (DSJ37) is herein placed at the top of the Glaucolithus Zone, rather than at the top of the Okusensis Zone, where this boundary was placed by Poulsen $(1991,1992,1996)$.

DSJ35; Middle Volgian (Albani Zone)

The base of the DSJ35 Zone is defined by the range base of consistent Dichadogonyaulax culmula and the apparent extinction of Occisucysta balia. The zone is the equivalent of the Dpa (a) Subzone of Riding \& Thomas (1992).

DSJ36; Middle Volgian (Glaucolithus Zone)

The base of the DSJ36 Zone is defined by the youngest occurrences of Leptodinium subtile and Scriniodinium inritibile.

DSJ37; Middle Volgian

(Okusensis-Anguiformis Zones)

The base of the DSJ37 Zone is defined by the range base of Dingodinium? spinosum. Within this zone, or at the top, the range top of Senoniasphaera jurassica is observed. This apparent extinction appears to occur in older strata in the British area than in the Danish onshore area.

\section{DSJ38-DSK2; Middle Volgian - Upper Ryazanian (Oppressus-Icenii Zones)}

The Pareodinia dasyforma and Gochteodinia villosa Zones of Davey $(1979,1982)$ were subdivided into three subzones. The names of the Egmontodinium expiratum, Rotosphaeropsis thula, and Endoscrinium pharo Subzones of Davey $(1979,1982)$ have been changed to follow the international guidelines whereby zonal names are changed in order to conform with any changes in the name of the index species (Hedberg 1976; Salvador 1994).

The broadly equivalent Gochteodinia villosa Zone of Woollam \& Riding (1983) and Riding \& Thomas (1992) 


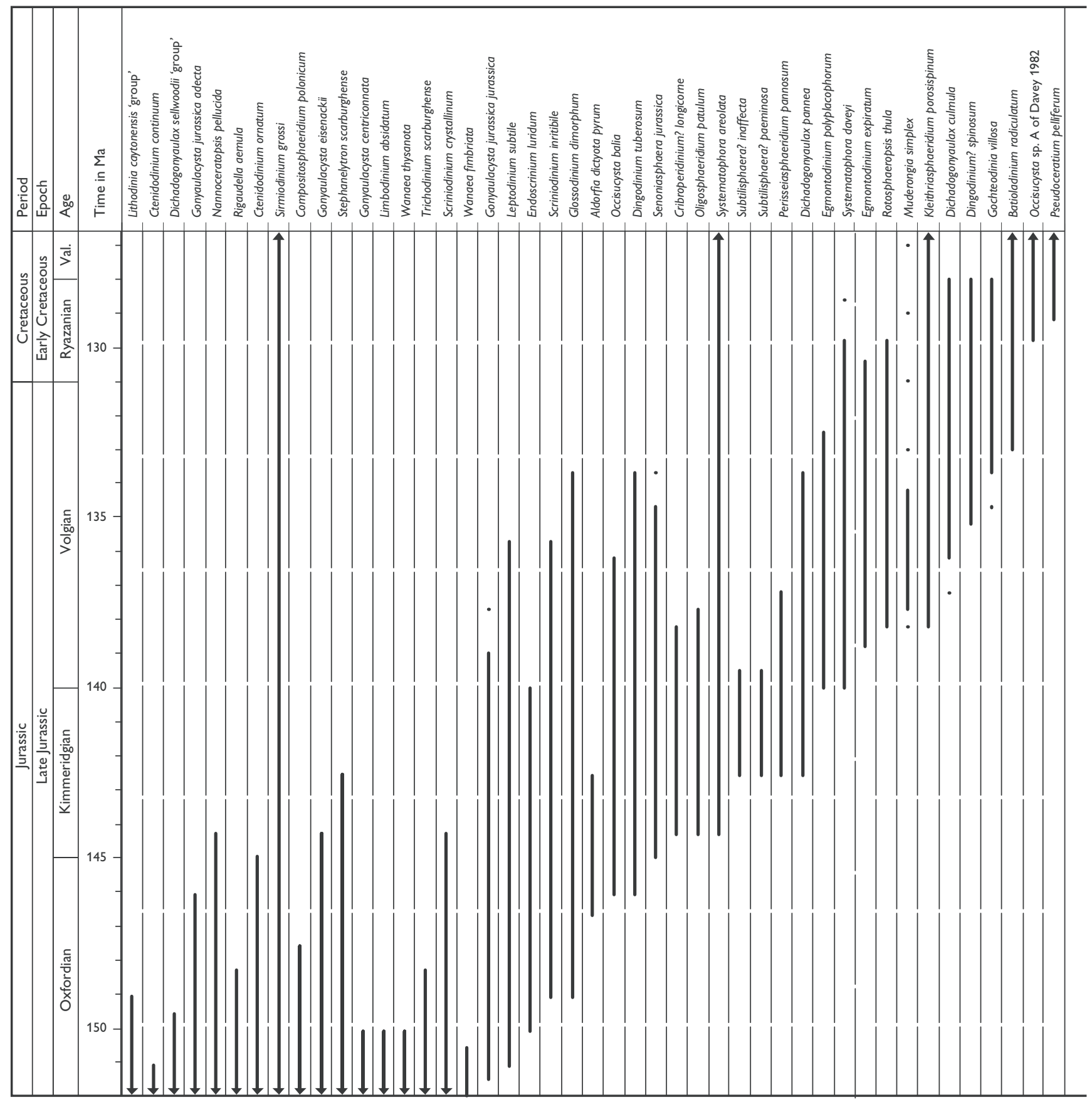

was divided into Subzones a to c by Woollam \& Riding (1983) and Riding \& Thomas (1992). The boundaries between Subzones a to c of Riding \& Thomas (1992) are different to those of the Egmontodinium expiratum, Rotosphaeropsis thula and Endoscrinium pharo Subzones of Davey $(1979,1982)$ and adopted by Poulsen (1991, 1992, 1996). The top of the Gochteodinia villosa Zone equivalent is herein regarded as being coincident with the top of the Icenii Zone. This is one chronozone lower than in the subdivisions of Davey $(1979,1982)$, Woollam \& Riding (1983), Riding \& Thomas (1992) and Poulsen (1996).

The Oppressus to Icenii Zone interval is herein subdivided into a four-fold subdivision, the DSJ38, DSJ39, DSK1 and DSK2 Zones (Fig. 5). 


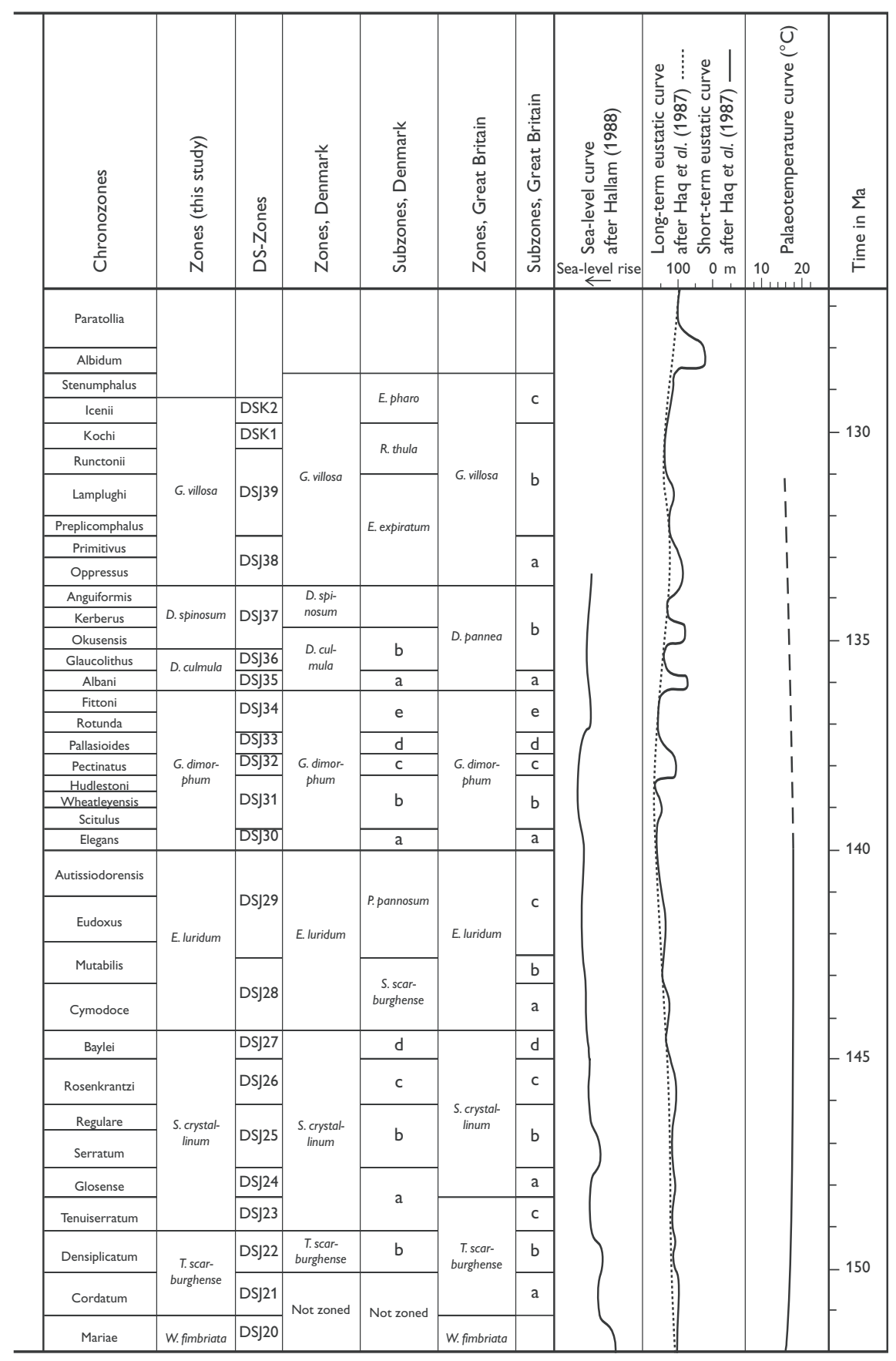

Fig. 5. Composite range chart for the key marker dinoflagellate cyst species in the Upper Jurassic - lowermost Cretaceous of the Subboreal region.

DSJ38; Middle-Upper Volgian

(Oppressus, Primitivus Zones)

The base of the DSJ38 Zone is defined by the youngest occurrences of Dichadogonyaulax? pannea, Dingodinium tuberosum and Glossodinium dimorphum and the oldest consistent occurrence of Gochteodinia villosa. This zone is therefore equivalent to Subzone a of the Gochteodinia villosa Zone of Riding \&
Thomas (1992) and the lower part of the Egmontodinium expiratum Subzone of Davey (1979, 1982).

DSJ39; Upper Volgian - Lower Ryazanian

(Preplicomphalus-Runctoni Zones)

The base of the DSJ39 Zone is defined by the range top of Egmontodinium polyplacophorum. This zone spans the Jurassic-Cretaceous boundary and is equiv- 
alent to the majority of Subzone b of the Gochteodinia villosa Zone of Riding \& Thomas (1992) and the upper part of the Egmontodinium expiratum Subzone and the lower Rotosphaeropsis thula Subzone of Davey $(1979,1982)$.

\section{DSK1; Lower Ryazanian (Kochi Zone)}

The top of the DSK1 Zone is defined by the youngest occurrence of Rotosphaeropsis thula. This zone is equivalent to the upper part of Subzone b of the Gochteodinia villosa Zone of Riding \& Thomas (1992) and the upper part of the Rotosphaeropsis thula Subzone of Davey $(1979,1982)$.

DSK2; Upper Ryazanian (Icenii Zone)

The base of the DSK2 Zone is defined by the youngest occurrence of Rotosphaeropsis thula and the oldest appearance of Occisucysta sp. A of Davey (1982). The top of this zone is defined by the oldest appearance of Pseudoceratium pelliferum. The range top of Systematophora daveyi is present at the lower boundary of this zone in the Danish Basin and the Danish North Sea. In the United Kingdom, this species occurs in younger strata. The DSK2 Zone is equivalent to the lower part of Subzone $\mathrm{c}$ of the Gochteodinia villosa Zone of Riding \& Thomas (1992) and the lower part of the Endoscrinium pharo Subzone of Davey $(1979,1982)$.

\section{The Jurassic dinoflagellate cyst zonation as proxy for palaeo- environmental changes}

The causal background for the spatial and temporal distributions of fossil and modern biotas is a function of the interplay of many factors. Among these parameters, salinity and water temperatures have direct importance in dinoflagellate cyst distribution patterns, whereas changes in sea level have an indirect influence by changing coastal to shelf environments (Wall et al. 1977; Stover et al. 1996). Before considering the palaeoecological implications of Jurassic dinoflagellate distributions, it is instructive to briefly outline the established palaeoclimatic and palaeo-oceanographic scenario for Jurassic times in Subboreal Northwest Europe.

\section{Jurassic sea-level change}

Jurassic sea-level changes are well-established in the literature and several high-resolution sea-level curves have been published (e.g. Haq et al. 1987; Hallam 1988, 1992b). Furthermore, stratigraphic analyses of sedimentary basins via the recognition of genetically-related stratal packages bounded by unconformities (sequences) have recently been developed by many workers such as Partington et al. (1993), Andsbjerg \& Dybkjær (2003, this volume) and Nielsen (2003, this volume).

\section{Jurassic palaeoclimates and ammonite provincialism}

Jurassic palaeoclimates were characterised by weaker temperature gradients and more uniform seawater temperatures than at present (Berggren \& Hollister 1974; Gordon 1975). Furthermore, the polar regions were significantly warmer than today without indications of continental glaciation (Arkell 1956; Donn 1982; Valdes \& Sellwood 1992). The numerical General Circulation Model presented by Valdes \& Sellwood (1992) may indicate somewhat lower palaeotemperatures for the Kimmeridgian than for other intervals of the Jurassic. However, the latter estimates appear to be inconsistent with other measurements and the geological record (see below). Organisms demanding a warm climate lived closer to the polar regions than today, even when continent migration due to plate tectonics is taken into account. For example, hermatypic corals have been reported from the Bathonian of East Greenland (Håkansson et al. 1971), a remarkable record as the northern proto-Atlantic Ocean was isolated from the Tethys Ocean during Bajocian and Bathonian times (Birkelund \& Perch-Nielsen 1976; Callomon 1985, 2003 , this volume)

Stahl \& Jordan (1969) measured palaeotemperatures between $18^{\circ} \mathrm{C}$ and $24^{\circ} \mathrm{C}$ from isotopic studies of ammonites from the German Aalenian and an average palaeotemperature of $13^{\circ} \mathrm{C}$ (with a range of $8-22^{\circ} \mathrm{C}$ ) from studies of septa in a Callovian ammonite from Poland. Tan et al. (1970) determined palaeotemperatures of $19-25^{\circ} \mathrm{C}$ from Early Callovian belemnites from Staffin Bay, Skye, north-west Scotland. These authors also demonstrated Middle Callovian palaeotemperatures of $21-24^{\circ} \mathrm{C}$ using belemnites, although ammonites from the same horizons revealed palaeotemperatures of $28-30^{\circ} \mathrm{C}$; Tan et al. (1970) noted, however, that the Middle Callovian ammonites are enriched in ${ }^{13} \mathrm{C}$, thereby giv- 
ing slightly higher calculated palaeotemperatures. Measurements of palaeotemperature based on material originating from palaeoenvironments with lower than fully marine palaeosalinities may give erroneously high values, some $2-3^{\circ} \mathrm{C}$ higher than normal (Donn 1982). The Subboreal Sea during the Jurassic exhibited significant palaeosalinity fluctuations (Hallam 1969; Fürsich \& Sykes 1977), which may explain the slightly higher measurements of Tan et al. (1970). Isotopic studies on coccoliths from the Kimmeridge Clay of Westbury, Wiltshire, England revealed a palaeotemperature of $20-30^{\circ} \mathrm{C}$ throughout the Early Kimmeridgian (Salinas 1984).

Although the Jurassic was characterised by less pronounced global marine temperature gradients than those of the present-day, palaeoecological studies and palaeothermometry have demonstrated that Jurassic palaeoclimatic variations were nevertheless significant. The palaeotemperature curve for the Jurassic in Figure 6 has been compiled by B. Buchardt (Table 2, Appendix 1). It suggests that the Early Jurassic was characterised by a general cooling until the latest Pliensbachian, followed by a rise which terminated at the Aalenian-Bajocian boundary. There followed a rapid palaeotemperature fall during the Bajocian, succeeded by minor fluctuations for the remainder of the Middle Jurassic. The Late Jurassic was characterised by a steady temperature rise until the Middle Volgian, after which time there was a period of cooling to the Jurassic-Cretaceous boundary (Fig. 6; Appendix 1).

Enay (1980) and Hallam (1983) stated that Jurassic palaeoclimates had a relatively minor influence on Jurassic provincialism, the biotic endemism observed being largely controlled by isolation related to plate tectonic events and sea-level changes. Similarly, Fürsich \& Sykes (1977) found that factors such as regional palaeotemperature and/or palaeosalinity gradients cannot alone explain the existence of the Boreal Realm dur-
Fig. 6. Jurassic palaeotemperature curve, courtesy of B. Buchardt (Appendix 1). The heavy black line connects the average isotopic temperature for each stage, whereas the grey envelope shows the scatter of individual isotopic results. True palaeotemperatures are believed to fall inside the grey envelope.

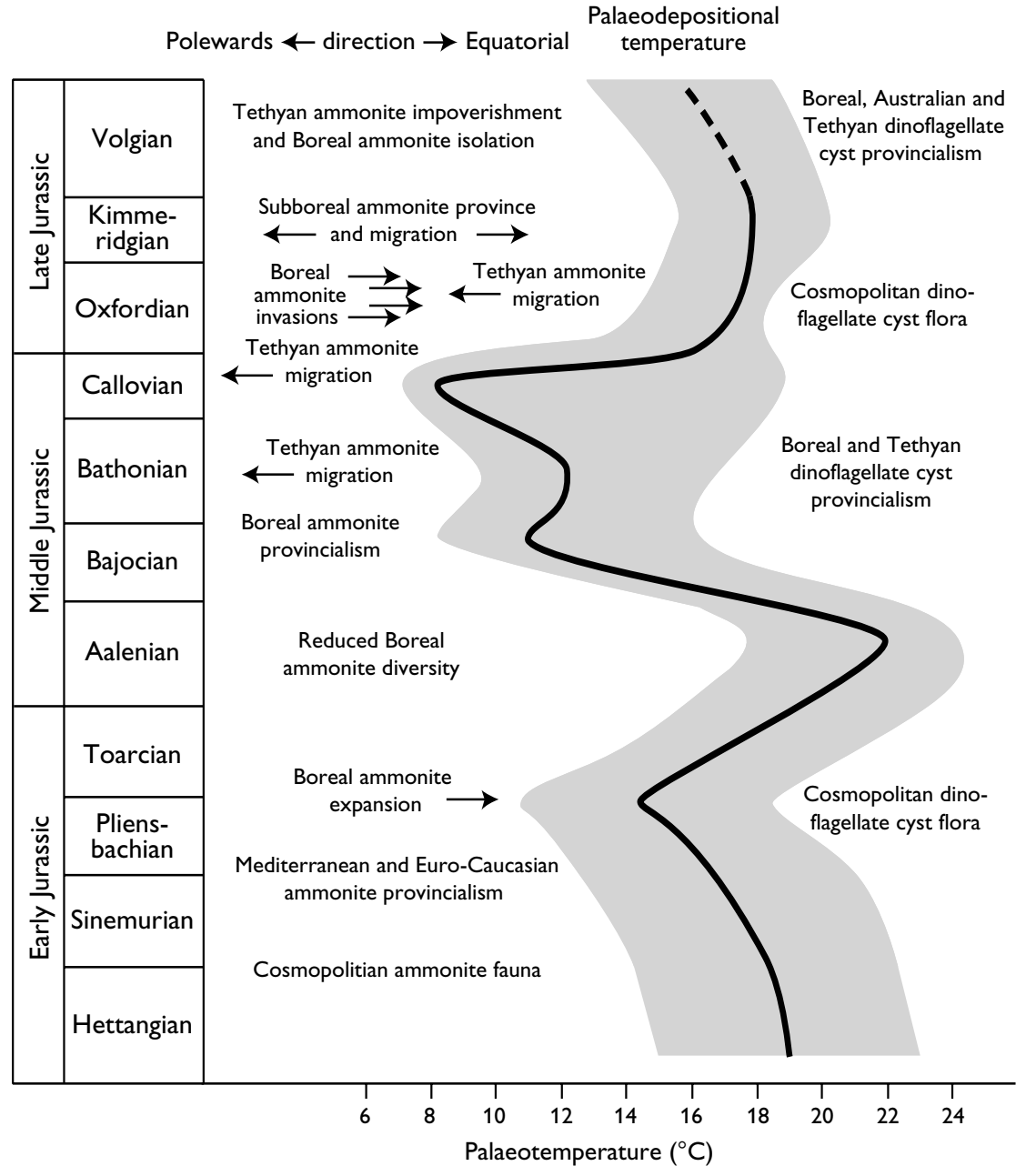


Table 2. Oxygen isotope palaeotemperatures for the Jurassic of Northwest Europe

\begin{tabular}{lcccr}
\hline Stage & $\begin{array}{c}\text { Average } \\
\text { temperature } \\
{ }^{\circ} \mathrm{C}^{*}\end{array}$ & $\begin{array}{c}\text { Range } \\
{ }^{\circ} \mathrm{C}\end{array}$ & $\begin{array}{c}\text { Number of } \\
\text { data points }\end{array}$ & References $^{\#}$ \\
\hline Volgian & no data & & & \\
Kimmeridgian & 18 & $15-20$ & 22 & $1,2,3,5$ \\
Oxfordian & 16 & $13-18$ & 18 & 1,2 \\
Callovian $^{+}$ & 17 & $14-20$ & 18 & 8 \\
Callovian $^{\ddagger}$ & 8 & $6-18$ & 13 & $2,3,4,7$ \\
Bathonian & 12 & $8-17$ & 8 & $1,4,9,10$ \\
Bajocian & 15 & $10-18$ & 20 & $1,2,3,4,6$ \\
Aalenian & 22 & $17-24$ & 17 & $2,3,4,7,9,10$ \\
Toarcian & 18 & $12-23$ & 39 & $1,2,3,4,9,10$ \\
Pliensbachian & 15 & $10-18$ & 21 & $1,2,3,4,9,10$ \\
Sinemurian & 17 & $13-21$ & 6 & 2 \\
Hettangian & 19 & $15-23$ & 5 & 2 \\
\hline
\end{tabular}

* Isotope palaeoptemperatures calculated from oxygen isotope values

according to the equation given by Craig (1965).

+ Data from Scotland, UK.

‡ Data from Germany.

\# References:

1: Bowen $(1961 \mathrm{a}, \mathrm{b})$

2: Fritz (1964)

3: Jordan \& Stahl (1970)

4: Kunz (1973)

5: Salinas (1984)

6: Spaeth et al. (1971)

7: Stahl \& Jordan (1969)

8: Tan et al. (1970)

9: Veizer (1974)

10: Veizer \& Fritz (1976)

ing the Oxfordian. The Late Jurassic palaeotemperature rises, however, appear to have controlled the migration of Tethyan faunas into the Boreal Realm. Furthermore, falling palaeotemperatures during the Jurassic caused Boreal faunal expansions or invasions into the Tethyan Realm (see below).

Ammonites were cosmopolitan during the earliest Jurassic (Hettangian and Sinemurian), but in the Early Pliensbachian and throughout the remainder of the Jurassic, ammonite provincialism was well-developed (Hallam 1971, 1973; Enay 1972, 1980; Callomon 1985, 2003, this volume; Cariou et al. 1985; Page 2003, this volume; Zeiss 2003, this volume). The Mediterranean and Euro-Caucasian Provinces were developed during the Pliensbachian and by the close of the stage a Boreal fauna made its first southerly incursion into the Tethyan Realm. The establishment of ammonite provincialism was coincident with falling palaeotemperatures and the following 'Boreal Expansion' corresponds to the Early Jurassic temperature minimum (Fig. 6). During the Toarcian to Early Bajocian period, Boreal ammonite faunas became less diverse as they expanded into the Tethyan Realm; this phenomenon is related to rising palaeotemperatures. Furthermore, doming in the Central

North Sea interrupted the passage from the Boreal Ocean to the Tethyan area (Sellwood \& Hallam 1974; Whiteman et al. 1975; Eynon 1981; Ziegler 1988; Underhill \& Partington 1993). During the Bathonian, Tethyan ammonite migration northwards towards the Boreal Ocean coincided with the opening of the passage through the United Kingdom and the North Sea, together with rising palaeotemperatures. The Boreal cardioceratid ammonite fauna developed during the Late Bathonian and Callovian and several Boreal ammonite 'expansions' have been recorded. These early incursions coincide with falling palaeotemperatures at this time. In the latest Callovian to Kimmeridgian, palaeotemperatures rose and Tethyan ammonite faunas migrated into the Boreal Realm. Several Boreal ammonite 'expansions' also occurred at this time. Although the average palaeotemperature rose during this period, the maximum temperature fell during the latest Callovian - Late Oxfordian (Fig. 6); this probably explains biotic migration from both the Boreal and Tethyan Realms. From the Late Oxfordian to the early Middle Volgian, the palaeotemperature rose and thereafter fell. During the Kimmeridgian, palaeotemperatures rose and a Subboreal ammonite fauna was developed which migrated towards both the Boreal and Tethyan Realms. Finally, during the Volgian, falling palaeotemperatures resulted in isolation of the Boreal Realm, and Tethyan impoverishment was recorded by the ammonite faunas (Hallam 1971, 1973; Enay 1972, 1980; Sykes \& Callomon 1979; Imlay 1980; Callomon \& Birkelund 1982; Birkelund \& Callomon 1985; Callomon 1985, 2003, this volume; Cariou et al. 1985; Wierzbowski 1989; Page 2003, this volume; Zeiss 2003, this volume).

\section{Jurassic dinoflagellate palaeoecology}

Jurassic dinoflagellate cyst provincialism is almost negligible compared to ammonite endemism (Enay 1972, 1980; Davies \& Norris 1981). Globally, Jurassic dinoflagellate cyst assemblages are of broadly similar generic/specific composition and a large number of species are cosmopolitan. Furthermore, they exhibit marked similarities in stratigraphic ranges throughout the world (Riding \& Ioannides 1996).

It appears that during the Early Jurassic, dinoflagellate cyst assemblages throughout Northwest Europe were broadly non-provincial. However, during the Aalenian pre-rift Central North Sea (Ziegler 1988; Underhill \& Partington 1993), a land barrier blocked North Sea marine communications and the dinoflagel- 
late cyst assemblages were consequently differentiated into the Boreal and Tethyan provinces (Smelror 1993; Riding \& Ioannides 1996). This barrier became submerged by rising sea levels during the Callovian, and Late Callovian and Oxfordian dinoflagellate cyst assemblages are cosmopolitan throughout Europe and adjacent regions (Raynaud 1978; Smelror 1993; Riding \& Ioannides 1996). However, during the Kimmeridgian and Volgian stages, Tethyan and Boreal-Australasian floras became established (Helby et al. 1987; Riding \& Ioannides 1996).

The assemblage diversity in the Northern Hemisphere also followed general ecological principles, with higher diversities in equatorial regions. For example, the Early Toarcian dinoflagellate cyst assemblages of southern Germany appear to be more diverse than coeval associations from the United Kingdom (Riding 1987; Riding \& Ioannides 1996). Other palaeoecological factors, however, clearly controlled dinoflagellate cyst diversity, as the Late Triassic and the Toarcian-Aalenian floras from the Sverdrup Basin, Arctic Canada are both significantly more diverse than their European counterparts (Davies 1983; Riding \& Ioannides 1996).

Dinoflagellate cyst associations were affected by a number of inter-related factors such as latitude, climate (temperature), water depth, marine currents, nutrient supply, inter-basin seaways, barriers, distance from shoreline and salinity. For much of the Jurassic, dinoflagellate cyst assemblages in the Subboreal Realm appear to have been influenced by these parameters, particularly palaeotemperature/climate, palaeobathymetry (sealevel fluctuations) and seaways. The distribution patterns of Late Jurassic dinoflagellate cysts with low and high surface relief are related to cold and warm water, respectively, according to Dörhöfer (1977). Lentin \& Williams (1980) established that high relief cyst surfaces and processes are a flotation adaptation necessary in warm water (the specific gravity of water is 1.00000 at $4^{\circ} \mathrm{C}$, falling to 0.99567 at $30^{\circ} \mathrm{C}$ ). This palaeoecological trend in the Jurassic was noted by Wierzbowski \& Århus (1990), Smelror (1993) and Riding \& Ioannides (1996); these authors found that complex process-bearing forms are more common in the Middle-Upper Jurassic of the Tethyan Realm compared to the Boreal Realm.

The seasonal variation in day length is another important ecological factor which is rarely considered in studies of phytoplankton provincialism (Reid 1973). Figure 2 illustrates the position of the Pliensbachian, Toarcian and Volgian north poles, in addition to the approximate geographical extent of the Pliensbachian and Volgian two-month polar night, giving seasonal variations in day length and sunlight intensity. Such variations will have increased towards the poles, independent of climate and climatic zones. This must have been an important factor in a period during which heat-demanding plants and animals lived at higher latitudes compared to the present. The seasonal variations in day length and sunlight intensity would have had a major influence on phytoplankton during Jurassic times and thereby also on higher links in the food chain (Hallam 1973; Reid 1973). The position of the two-month polar night moved during the Jurassic from a position in the Jurassic Arctic Sea near north-east Siberia to a position between Siberia and Alaska (Fig. 2). This may have reduced biotic migration between the proto-Arctic Ocean and the Pacific, especially in the latest Jurassic, thereby compounding increasing provincialism in the latest Jurassic caused by falling temperatures in the Kimmeridgian-Volgian (Figs 2-6).

\section{Biozonation, palaeotemperature and sea-level changes}

In the Late Sinemurian, eustatic fluctuations appear to have been critical for dinoflagellate cyst floras. At this time, a sea-level rise (Fig. 3) appears to have controlled the earliest occurrence of Liasidium variabile; this species is considered to be related to deeper marine conditions. Its occurrence may be related to migration as a consequence of the rising sea-level. The latest Sinemurian sea-level fall (Fig. 3) may have caused the apparent extinction of Liasidium variabile.

Cooling during the earliest Jurassic may explain the apparent earlier extinction of Dapcodinium priscum in the Danish Basin than in the United Kingdom (see DSJ1-2 Zones, Fig. 3). Furthermore, Dapcodinium priscum ranges up to the lowermost Toarcian in Portugal (Davies 1985). Dapcodinium priscum was apparently a temperature-sensitive species which was confined to a relatively narrow palaeotemperature window. Thus it continued to live under warmer conditions in Portugal, although it disappeared from the Subboreal Province in the Early Sinemurian due to palaeoenvironmental factors (Riding \& Thomas 1992).

The Middle-Late Pliensbachian sea-level highstand corresponds to the inception of the genus Nannoceratopsis, as manifested by the first appearance of Nannoceratopsis senex. During the Late Pliensbachian - Middle Toarcian sea-level rise, several dinoflagellate cyst species appeared including other species of Nannoceratopsis (DSJ5-6 Zones, Fig. 3). Several of these forms 
have apparent extinctions in the earliest Toarcian, possibly caused by a fall in sea level (Fig. 3), and the latest Pliensbachian palaeotemperature minimum (Fig. 6).

The Lower Toarcian (DSJ7-8 Zones) is marked by widespread indications of restricted marine conditions resulting from a rapid sea-level rise (Gorin \& FeistBurkhardt 1990). The succeeding Middle Toarcian to earliest Aalenian short-term sea-level changes are reflected in the United Kingdom by a greater degree of zonal subdivision (DSJ8-10) than in the Danish Basin where Zones DSJ9 and DSJ10 cannot be differentiated (Figs 3, 4). The inception of the marker species Nannoceratopsis dictyambonis, which defines the boundary between the DSJ9 and DSJ10 Zones, and the biostratigraphically important species Nannoceratopsis ambonis, Scriniocassis priscus and Scriniocassis weberi, are not observed in the Danish Basin (Poulsen 1992, 1996), although they are characteristic elements both in the United Kingdom (Woollam \& Riding 1983; Riding 1987) and Germany (Prauss 1989). Sea-level change in more proximal (i.e. shallow-water) parts of the North Sea region may have been an important controlling factor, especially in the Danish Basin, where ammonites and ostracods are also absent in the Toarcian (Sorgenfrei \& Buch 1964; Michelsen 1975; Poulsen 1996). Furthermore, the palaeotemperature rises influenced changes in the carbon reservoir and may have had a controlling effect on the palaeoenvironment (Gorin \& Feist-Burkhardt 1990). This effect may especially have influenced the environment in Denmark during the Toarcian.

Palaeotemperatures rose weakly during the Aalenian, fell sharply in the Bajocian and weakly in the Bathonian - Middle Callovian before rising again in the latest Callovian (Fig. 6). This is reflected in the northward migration of Tethyan floras from the Aalenian to the Bajocian. This migration ceased later in the Bajocian and Bathonian (see below). The Middle Jurassic thermal doming in the North Sea started in the Late Toarcian and led to non-marine to marginal marine sedimentation in the North Sea area (Underhill \& Partington 1993; Nielsen 2003, this volume). The dinoflagellate cyst record is interrupted in Denmark above the DSJ10 Zone. In the United Kingdom, the zonation may be interpreted as an interaction between variations in palaeotemperature and sea level. The Nannoceratopsis gracilis Zone (DSJ11-12 Zones) broadly corresponds to the Middle Aalenian - Early Bajocian sea-level rise (Fig. 4). The following sea-level maximum and fall (Fig. 4) correlates to the DSJ13-16 Zones with the DSJ14-15 zonal boundary corresponding to the Middle Bathonian shortterm sea-level minimum (Fig. 4). The DSJ17-20 zonal boundaries do not appear to have been related to known sea-level changes (Fig. 4).

Fenton \& Fisher (1978) demonstrated that the Bathonian transgressive phase controlled dinoflagellate cyst migrations from Germany and southern England to eastern England and the Central Graben in the North Sea. These authors also compared the Aspidoides Zone in the United Kingdom, France, East Greenland and Spain and found that although certain species are consistently present, there are significant compositional differences in these assemblages. Fenton \& Fisher (1978) noted that species of Ctenidodinium in the United Kingdom were more common south of the LondonBrabrant Massif than to the north, with C. combazii and $C$. ornatum dominant, and that $C$. combazii was not recorded north of the massif. In the Aquitane Basin, south-west France, the assemblages comprise approximately 90\% C. combazii, whereas to the north, in the Paris Basin near Poitiers, the assemblages are dominated by acritarchs with only relatively rare representatives of Ctenidodinium (including C. combazii) and Lithodinia (Valensi 1953; Dupin 1965; Fenton \& Fisher 1978). In eastern England, Bathonian dinoflagellate cyst assemblages are dominated by species of Chytroeisphaeridia, Ctenidodinium, Lithodinia and Sentusidinium. Fenton \& Fisher (1978) concluded that highly sculptured species were common in the southern region, whereas the Boreal assemblages include many smooth forms and that the Callovian transgression resulted in a northern spread of sculptured forms (Fig. 7).

Investigations of the Bathonian-Callovian from northwest Germany (Gocht 1970; Fenton 1981), the Netherlands (Herngreen \& de Boer 1978) and the United Kingdom (Sarjeant 1959, 1976; Neves \& Selley 1975; Lam \& Porter 1977; Muir \& Sarjeant 1978; Fenton et al. 1980; Woollam 1980, 1982; Riding 1982; Riding et al. 1991) have identified significant differences between the Tethyan Ctenidodinium-dominated assemblages and their Boreal counterparts. The latter include shallowwater, proximal assemblages with Ctenidodinium continuum, C. ornatum, Dichadogonyaulax sellwoodii, Lithodinia spp., Nannoceratopsis spp., Pareodinia spp. and Valensiella ovula. It appears that the Tethyan floras migrated northwards from southern England during the latest Bajocian - earliest Bathonian. A mixed Tethyan-Boreal flora is recognised further north in Oxfordshire and Cambridgeshire, central England, in the Upper Bathonian - Lower Callovian and in Scotland in the Middle Callovian. The northwards migration of Ctenidodinium combazii and related species appears to have been in response to warming during the Late 


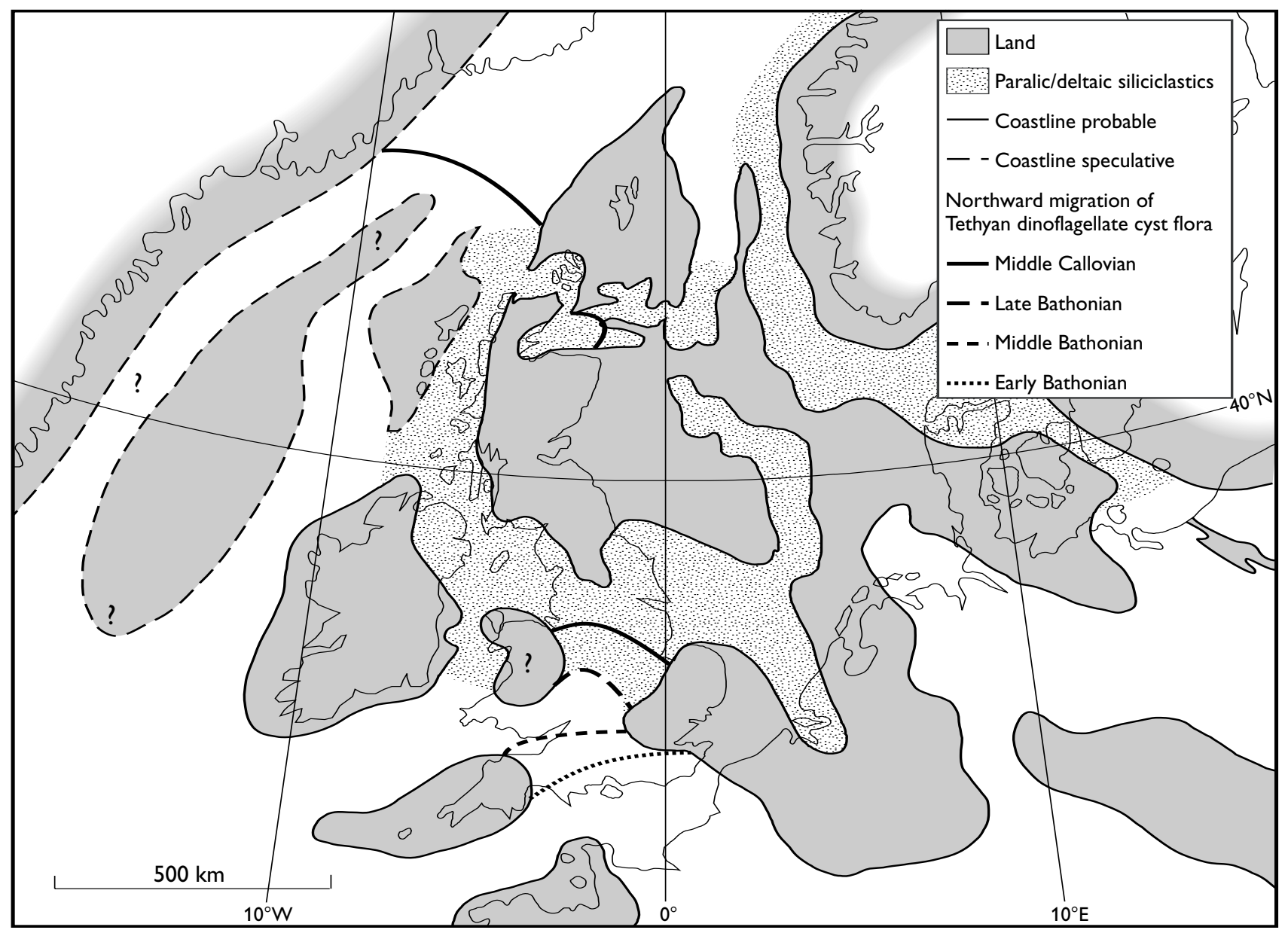

Fig. 7. Palaeogeographical map of the North Sea area during the Middle Jurassic (modified slightly from Callomon 2003, this volume) showing the progressive northwards migration of Tethyan dinoflagellate cysts.

Bajocian - Middle Bathonian (Figs 6, 7). This northerly incursion of Tethyan floras ceased in the Middle Bathonian and a mixed flora is present in central and northern England; this event coincides with falling palaeotemperatures as well as falling sea-level in the Bajocian - Middle Callovian.

The Middle Jurassic floras with common Nannoceratopsis gracilis and Valensiella ovula may be indicative of shallow-water, relatively nearshore settings, rather than these associations having Boreal affinities. This assemblage type was displaced by a more diverse Tethyan flora due to rising sea-levels in the Bajocian (Fig. 4). Nannoceratopsis gracilis has been described as a euryhaline species, tolerant of reduced palaeosalinities (Fisher 1980; Bucefalo Palliani \& Riding 1997). It was described by Fensome (1979) as a dominant species in a restricted marine palaeoenvironment (see also Surlyk et al. 1973). This taxon has been reported from shallow-water marine to deltaic swamp facies of Yorkshire by Hancock \& Fisher (1981). Davey (1979), however, described $N$. gracilis as being abundant in normal marine sediments together with Valensiella ovula and related forms. Valensiella ovula was deemed to be a Boreal species by Norris (1975), although it has been reported from Bulgaria (Dodekova 1975) which was within the Tethyan Realm. Furthermore, this species has not been recorded from northern North America. In East Greenland, it was recorded by Fensome (1979) in a shallow shelf palaeoenvironment (Surlyk et al. 1981). Palmer \& Jenkyns (1975) described the Bathonian palaeoenvironment in the area north of the LondonBrabrant Massif in England as fresh to brackish water lagoons (the Oxfordshire shallows). Towards the south, these lagoons became gradually more marine and were replaced by fully marine carbonate shelf palaeoenvironments in Dorset, southern England. Not only did the 
facies change in relation to palaeotemperature variations, but also from non-marine to marginal marine and further to fully marine.

The Oxfordian and Kimmeridgian Stages were characterised by rising palaeotemperatures and relatively minor, short-term, sea-level changes (Figs 5, 6). The dinoflagellate cyst zonation appears to be a reflection of both of these factors. Provincialism was developed in the Kimmeridgian-Volgian interval. Falling palaeotemperatures and repeated, short-term eustatic changes in the Volgian appear to be expressed in the zonation. In the Danish Basin, lowermost Middle Oxfordian marine deposits succeed fluviatile Middle Jurassic deposits (Poulsen 1992, 1996; Nielsen 2003, this volume). At this time, the distribution of dinoflagellate cysts became uniform over the entire British-Danish area (Poulsen 1996).

Raynaud (1978) compared the Callovian to Volgian (Tithonian) dinoflagellate cyst record in the United Kingdom and the North Sea and found broad similarities between the areas, although quantitative differences were discerned. These differences were most pronounced in the Kimmeridgian to Volgian (Tithonian) interval. According to Raynaud (1978), Late Callovian - Early Oxfordian floras were uniform throughout Arctic Canada, East Greenland, Europe and Svalbard (Beju 1971; Johnson \& Hills 1973; Tan \& Hills 1978; Bjærke 1980; Poulsen 1984). The rising palaeotemperatures during the Late Callovian and Oxfordian, together with the marine connection between the Boreal and Tethyan oceans, appear to have created a cosmopolitan floral province during this interval in the Northern Hemisphere.

The majority of Upper Jurassic dinoflagellate cyst zonal boundaries were probably influenced by Late Jurassic eustatic oscillations (Fig. 5). For example, the DSJ28-29 zonal boundary coincides with the short-term sea-level fall following the mid-Kimmeridgian maximum. In contrast, the DSJ29-30 zonal boundary (the top of the Endoscrinium luridum Zone) corresponds approximately to the sea-level maximum in the latest Kimmeridgian. Similarly, many of the boundaries of the DSJ30-38 Zones correlate broadly with sea-level minima or maxima of the short-term eustatic curve of Haq et al. (1987; Fig. 5). The upper boundary of the Glossodinium dimorphum Zone (the DSJ34-35 zonal boundary) approximates to a short-term sea-level maximum. The boundary between the Dingodinium? spinosum and the Gochteodinia villosa Zones (DSJ37-38) coincides with the short-term sea-level maximum at the close of the Volgian (Fig. 5). Most of the zonal boundaries that correlate broadly with eustatic events have been recorded slightly later than the sea-level minima and maxima, and may be related to shifts in sedimentary facies from clay to sand (e.g. from the Kimmeridge Clay to Portland Sand Formations or from the Børglum to Frederikshavn Formations in Dorset and Jylland, respectively).

Kimmeridgian - Early Volgian dinoflagellate cyst assemblages are rich; the high diversities reflect correspondingly high sea levels. Rich nearshore assemblages of latest Kimmeridgian - earliest Volgian age have been recorded in Denmark at the margin of the Baltic Shield (Poulsen 1996), indicating the maximum extent of the Børglum Formation (Kimmeridge Clay Formation equivalent) over the Baltic Shield. Marine conditions existed continuously in Denmark during the Volgian to Ryazanian, although non-marine phases occurred near the margin of the Baltic Shield (Poulsen 1996). Poulsen (1992; 1996) considered Volgian and Ryazanian palaeoenvironments and identified floral events in Denmark which were thought to reflect eustatic changes. These events are more readily identified in shallow shelf deposits than in the deeper water succession of the Central Graben. Low diversity dinoflagellate cyst assemblages in the lower part of the DSJ39 Zone were recorded in Denmark by Poulsen (1996), who related them to eustatic rise and fall during the latest Jurassic. The rich assemblages within the upper part of the DSJ39 Zone correspond to the sea-level rise at the Jurassic-Cretaceous boundary (Poulsen 1996). Less diverse assemblages recorded from the lowermost Cretaceous (DSK1-2 Zones) are related to successive marine highstands and lowstands (Poulsen 1996). The richer assemblages from the overlying Pseudoceratium pelliferum Subzone have been related to the succeeding sea-level rise (Poulsen 1996).

The lowermost Cretaceous of Denmark is characterised by rich dinoflagellate cyst assemblages which include a variety of pareodiniacean dinoflagellate cysts, thereby suggesting affinities to the Boreal Realm (Poulsen 1996). This corresponds to falling palaeotemperatures close to the Jurassic-Cretaceous boundary (Fig. 6). Late Ryazanian assemblages are characterised by a decrease in the abundance and diversity of dinoflagellate cysts in the DSK2 Zone and younger strata. Lott et al. (1989) also noted this phenomenon and related the differences to a latest Ryazanian transgression. It is believed, therefore, that the dinoflagellate cyst diversity and abundance fluctuations correspond well to both the sealevel changes at the Jurassic-Cretaceous boundary proposed by Haq et al. (1987), and to the model of Rawson \& Riley (1982). 


\section{Conclusions}

The stepwise evolution of dinoflagellate cyst assemblages, as defined by inceptions and apparent extinctions, appears to have been largely controlled by sea-level changes, particularly during intervals with significant short-term eustatic fluctuations. In times of less pronounced, or more long-term sea-level changes, fluctuations in the marine palaeotemperature seem to have influenced dinoflagellate evolution. Differences in the ranges of certain taxa between Denmark and the United Kingdom are ascribed to minor palaeotemperature differences.

The Early Jurassic was characterised by a general cooling until the Late Pliensbachian. The zonation can be related to sea-level changes, although the slightly different ranges of some of the index species in Denmark compared to the United Kingdom can be explained by minor palaeotemperature differences. The Late Toarcian - Aalenian thermal doming event in the North Sea resulted in non-marine to marginal marine sedimentation during Late Aalenian - Bathonian times in the North Sea and Denmark, such that the dinoflagellate cyst zonation is often difficult to apply in this stratigraphic interval. In the United Kingdom, however, the zonation can be interpreted to reflect the interaction between the general falling palaeotemperature and sea-level changes. The Oxfordian-Kimmeridgian was characterised by warming and short-term sea-level changes. The dinoflagellate cyst zonation appears to record both these factors, sometimes together, sometimes singly. The falling palaeotemperature and the short-term sea-level changes in the Volgian are expressed in the zonation, in addition to increased provincialism.

Comparison of the zonation scheme with the shortterm sea-level curve demonstrates that the DS Zones in the Subboreal Province (subzones in the earlier zonation scheme for the British-Danish area, see Figs 3-5) often correlate with the short-term sea-level minima of Haq et al. (1987). However, many of the zonal boundaries in the earlier British-Danish zonation scheme correlate with short-term sea-level maxima on the Haq et al. (1987) sea-level curve.

Hallam (1983) stated that Jurassic palaeoclimates had only a minor influence on Jurassic provincialism, and that any biotic endemism was largely controlled by plate tectonic events and sea-level changes. However, increases in Jurassic palaeotemperatures allied to palaeooceanographic factors appear to have controlled the migration of Tethyan biotas northward into the Boreal Realm. Furthermore, falling Jurassic palaeotemperatures caused Boreal spreads or invasions southwards into the Tethyan Realm.

\section{Acknowledgements}

We wish to express our sincere thanks to colleagues at our respective institutes for their help and interest, and to the referees, Roger J. Davey and Don G. Benson, for their constructive reviews. J.B.R. publishes with the permission of the British Geological Survey.

\section{References}

Including references cited in Appendix 1

Andrews, I.J., Long, D., Richards, P.C., Thomson, A.R., Brown, S., Chesher, J.A. \& McCormac, M. 1990: United Kingdom offshore regional report: the geology of the Moray Firth, 106 pp. London: Her Majesty's Stationery Office for the British Geological Survey.

Andsbjerg, J. \& Dybkjær, K. 2003: Sequence stratigraphy of the Jurassic of the Danish Central Graben. In: Ineson, J.R. \& Surlyk, F. (eds): The Jurassic of Denmark and Greenland. Geological Survey of Denmark and Greenland Bulletin 1, 265-300 (this volume).

Arkell, W.J. 1956: Jurassic geology of the World, 806 pp. Edinburgh, London: Oliver \& Boyd.

Batten, D.J. \& Lister, J.K. 1988: Evidence of freshwater dinoflagellates and other algae in the English Wealden (Early Cretaceous). Cretaceous Research 9, 171-179.

Beju, D. 1971: Jurassic microplankton from the Carpathian foreland of Roumania. Annales Instituti Geologici Publici Hungarici 54, 275-317.

Berggren, W.A. \& Hollister, C.D. 1974: Plate tectonics: a revolution in geology and geophysics. Tectonophysics 38, 1-48.

Birkelund, T. \& Callomon, J.H. 1985: The Kimmeridgian ammonite faunas of Milne Land, central East Greenland. Bulletin Grønlands Geologiske Undersøgelse 153, 56 pp.

Birkelund, T. \& Perch-Nielsen, K. 1976: Late Palaeozoic - Mesozoic evolution of central East Greenland. In: Esher, A. \& Watt, W.S. (eds): Geology of Greenland, 304-339. Copenhagen: Geological Survey of Greenland.

Bjærke, T. 1980: Mesozoic palynology of Svalbard V. Dinoflagellates from the Agardhfjellet Member (Middle and Upper Jurassic) in Spitsbergen. Norsk Polarinstitutt Skrifter 172, 145-167.

Bowen, R. 1961a: Oxygen isotope paleotemperature measurements on Cretaceous Belemnoidea from Europe, India and Japan. Journal of Paleontology 35, 1077-1084.

Bowen, R. 1961b: Paleotemperature analyses of Mesozoic Belemnoidea from Germany and Poland. Journal of Geology 69, 75-83.

Brooks, J.R.V. \& Chesher, J.A. 1975: Review of the offshore Jurassic of the UK Northern North Sea. In: Finstad, K.G. \& Selley, R.C. (coordinators): Jurassic Northern North Sea Symposium, Stavanger, 28-30 September, 1975. Norwegian Petroleum Society (NPF) Proceedings JNNS/2, 1-24. 
Bucefalo Palliani, R. \& Riding, J.B. 1997: Influence of palaeoenvironmental change on dinoflagellate cyst distribution. An example from the Lower and Middle Jurassic of Quercy, southwest France. Bulletin du Centres de Recherches Elf Exploration Production 21, 107-123.

Buchardt, B. \& Weiner, S. 1988: Diagenesis of aragonite from Upper Cretaceous ammonites, a case-study. Sedimentology $\mathbf{2 8}$, 423-438.

Callomon, J.H. 1984: Biostratigraphy, chronostratigraphy and all that - again! In: Michelsen, O. \& Zeiss, A. (eds): International Symposium on Jurassic stratigraphy (Erlangen 1984) 3, 611-624. Copenhagen: Geological Survey of Denmark.

Callomon, J.H. 1985: The evolution of the Jurassic ammonite family Cardioceratidae. In: Cope, J.C.W. \& Skelton, P.W. (eds): Evolutionary case histories from the fossil record. Special Papers in Palaeontology 33, 49-90.

Callomon, J.H. 2003: The Middle Jurassic of western and northern Europe: its subdivisions, geochronology and correlations. In: Ineson, J.R. \& Surlyk, F. (eds): The Jurassic of Denmark and Greenland. Geological Survey of Denmark and Greenland Bulletin 1, 61-73 (this volume).

Callomon, J.H. \& Birkelund, T. 1982: The ammonite zones of the Boreal Volgian (Upper Jurassic) in East Greenland. In: Embry, A.F. \& Balkwill, H.R. (eds): Arctic geology and geophysics. Canadian Society of Petroleum Geologists Memoir 8, 349-369.

Cameron, T.D.J., Crosby, A., Balson, P.S., Jeffery, D.H., Lott, G.K., Bulat, J. \& Harrison, D.J. 1992: United Kingdom offshore regional report: the geology of the southern North Sea, 152 pp. London: Her Majesty's Stationery Office for the British Geological Survey.

Cariou, E., Contini, D., Dommergues, J.-L., Enay, R., Geyssant, J.R., Mangold, C. \& Thierry, J. 1985: Biogéographie des ammonites et évolution structurale de la Tethys au cours du Jurassique. Bulletin de la Société géologique de France Série 8 1(5), 679-697.

Cope, J.C.W., Duff, K.L., Parsons, C.F., Torrens, H.S., Wimbledon, W.A. \& Wright, J.K. 1980a: A correlation of Jurassic rocks in the British Isles. Part Two: Middle and Upper Jurassic. Geological Society Special Report (London) 15, 109 pp.

Cope, J.C.W., Getty, T.A., Howarth, M.K., Morton, N. \& Torrens, H.S. 1980b: A correlation of Jurassic rocks in the British Isles. Part One: Introduction and Lower Jurassic. Geological Society Special Report (London) 14, 73 pp.

Cox, B.M. 1990: A review of Jurassic chronostratigraphy and age indicators for the UK. In: Hardman, R.F.P. \& Brooks, J. (eds): Tectonic events responsible for Britain's oil and gas reserves. Geological Society Special Publication (London) 55, 169-190.

Craig, H. 1965: The measurement of oxygen isotope paleotemperatures. Proceedings of the Spoleto Conference on stable isotopes (Pisa) 1965, 161-182.

Czaplicka, J. (ed.) 1976: Geology of Poland 1(2), 859 pp. Warsaw: Wydawnictwa Geologiczne.

Davey, R.J. 1979: The stratigraphic distribution of dinocysts in the Portlandian (latest Jurassic) to Barremian (Early Cretaceous) of Northwest Europe. American Association of Stratigraphic Palynologists Contributions Series 5B, 49-81.

Davey, R.J. 1982: Dinocyst stratigraphy of the latest Jurassic to
Early Cretaceous of the Haldager No. 1 borehole, Denmark. Geological Survey of Denmark Series B 6, 57 pp.

Davey, R.J. \& Riley, L.A. 1978: Late and Middle Jurassic dinoflagellate cysts. In: Thusu, B. (ed.): Distribution of biostratigraphically diagnostic dinoflagellate cysts and miospores from the Northwest European continental shelf and adjacent areas. Continental Shelf Institute Publication 100, 31-45. (Institutt for Kontinentalsokkelunders $\varnothing$ kelser (IKU), Trondheim, Norway).

Davies, E.H. 1983: The dinoflagellate Oppel-zonation of the Jurassic - Lower Cretaceous sequence in the Sverdrup Basin, Arctic Canada. Geological Survey of Canada Bulletin 359, 60 pp.

Davies, E.H. 1985: The miospore and dinoflagellate cyst Oppelzonation of the Lias of Portugal. Palynology 9, 105-132.

Davies, E.H. \& Norris, G. 1981: Latitudinal variations in encystment modes and species diversity in Jurassic dinoflagellates. Geological Association of Canada Paper 20, 361-373.

de Vernal, A., Londeix, L., Mudie, P.J., Harland, R., MorzadecKerfourn, M.-T., Turon, J.-L. \& Wrenn, J.H. 1992: Quaternary organic-walled dinoflagellate cysts of the North Atlantic Ocean and adjacent seas: ecostratigraphy and biostratigraphy. In: Head, M.J. \& Wrenn, J.H. (eds): Neogene and Quaternary dinoflagellate cysts and acritarchs, 289-328. Dallas: American Association of Stratigraphic Palynologists Foundation.

Dodekova, L. 1975: New Upper Bathonian dinoflagellate cysts from northeastern Bulgaria. Bulgarian Academy of Sciences. Palaeontology, Stratigraphy, Lithology 2, 17-34.

Donn, W.L. 1982: The enigma of high-latitude paleoclimate. In: Barron, E.J. (ed.): Paleogeography and climate. Palaeogeography, Palaeoclimatology, Palaeoecology 40, 199-212.

Dörhöfer, G. 1977: Principles of dinoflagellate cyst provincialism. Coloquio Internacional de Palinologia 1977 (León, España). Abstract volume, 5 only.

Dupin, F. 1965: Contribution á l'étude paléoplanctonique du Jurassique en Aquitaine occidentale. Actes de la Société linneènne de Bordeaux 102, 1-19.

Edwards, L.E. 1984: Insights into why graphic correlation (Shaw's method) works. Journal of Geology 92, 583-587.

Edwards, L.E. 1989: Supplemented graphic correlation: a powerful tool for paleontologists and nonpaleontologists. Palaios 4, 127-143.

Enay, R. 1972: Paléobiogéographie des ammonites du Jurassique terminal (Tithonique/Volgien/Portlandien s.l.) et mobilité continentale. Geobios 5, 355-407.

Enay, R. 1980: Paléobiogéographie et ammonites Jurassiques: 'rythmes fauniques' et variations du niveau marin; voirs d'échanges, migrations et domaines biogéographiques. Extrait du Livre Jubilaire de la Société géologique de France Memoir 10, 261-281.

Epstein, S. \& Lowenstam, H.A. 1953: Temperature-shell-growth relations of recent and interglacial Pleistocene shoal-water biota from Bermuda. Journal of Geology 61, 424-438.

Epstein, S., Buchsbaum, R., Lowenstam, H.A. \& Urey, H.C. 1951: Carbonate-water isotopic temperature scale. Geological Society of America Bulletin 62, 417-425.

Erlström, M., Guy-Ohlson, D. \& Sivhed, U. 1994: Palaeoecology and sedimentary environments of the Jurassic-Cretaceous transition beds in Sweden. Geobios 17, 671-678. 
Evitt, W.R. 1985: Sporopollenin dinoflagellate cysts. Their morphology and interpretation, 333 pp. Dallas: American Association of Stratigraphic Palynologists Foundation.

Eynon, G. 1981: Basin development and sedimentation in the Middle Jurassic of the northern North Sea. In: Illing, L.V. \& Hobson, G.D. (eds): Petroleum geology of the continental shelf of North-West Europe: proceedings of the 2nd conference. London: Heyden \& Son Ltd.

Fensome, R.A. 1979: Dinoflagellate cysts and acritarchs from the Middle and Upper Jurassic of Jameson Land, East Greenland. Bulletin Grønlands Geologiske Undersøgelse 132, 98 pp.

Fenton, J.P.G. 1981: Taxonomic revision of selected dinoflagellate cysts from the Late Bajocian (Middle Jurassic) of Northwest Germany. Review of Palaeobotany and Palynology 31, 249-260.

Fenton, J.P.G. \& Fisher, M.J. 1978: Regional distribution of marine microplankton in the Bajocian and Bathonian of north-west Europe. Palínologia, número extraordinario 1, 233-243.

Fenton, J.P.G., Neves, R. \& Piel, K.M. 1980: Dinoflagellate cysts and acritarchs from Upper Bajocian to Middle Bathonian strata of central and southern England. Palaeontology 23, 151-170.

Fisher, M.J. 1980: Kerogen distribution and depositional environments in the Middle Jurassic of Yorkshire, UK. Proceedings of the 4th International Palynological Conference (Lucknow) 2, 574-580.

Fisher, M.J. \& Riley, L.A. 1980: The stratigraphic distribution of dinoflagellate cysts at the boreal Jurassic-Cretaceous boundary. Proceedings of the 4th International Palynological Conference (Lucknow) 2, 313-329.

Fritz, P. 1964: ${ }^{18} \mathrm{O} /{ }^{16} \mathrm{O}-$ Isotopanalysen und Paläotemperaturbestimmungen an Belemniten aus dem Schwäbischen Jura. Geologische Rundschau 54, 261-269.

Fritz, P. \& Poplawski, S. 1974: ${ }^{18} \mathrm{O}$ and ${ }^{13} \mathrm{C}$ in the shells of freshwater molluscs and their environments. Earth and Planetary Science Letters 24, 91-98.

Fürsich, F.T. \& Sykes, R.M. 1977: Palaeobiogeography of the European Boreal Realm during Oxfordian (Upper Jurassic) times: a quantitative approach. Neues Jahrbuch für Geologie und Paläontologie, Abhandlungen 155, 137-161.

Gocht, H. 1970: Dinoflagellaten-Zysten aus dem Bathonium des Erdölfeldes Aldorf (NW-Deutschland). Palaeontographica B 129, 125-165.

Gordon, W.A. 1975: Physical controls in marine biotic distribution in the Jurassic Period. In: Ross, C.A. (ed.): Paleogeographic provinces and provinciality. Society of Economic Paleontologists and Mineralogists Special Publication 21, 136-147.

Gorin, G.E. \& Feist-Burkhardt, S. 1990: Organic facies of the Lower to Middle Jurassic sediments in the Jura Mountains, Switzerland. Review of Palaeobotany and Palynology $\mathbf{6 5}$, 349-355.

Guy-Ohlson, D. 1986: Jurassic palynology of the Vilhelmsfält Bore No. 1, Scania, Sweden, Toarcian-Aalenian, 127 pp. Stockholm: Section of Palaeobotany, Swedish Museum of Natural History.

Guy-Ohlson, D. \& Norling, E. 1988: Upper Jurassic litho- and biostratigraphy of NW Scania, Sweden. Sveriges Geologiska Undersökning Serie Ca 72, 37 pp.

Håkansson, E., Birkelund, T., Piasecki, S. \& Zakharov, V. 1971:
Jurassic-Cretaceous boundary strata of the extreme Arctic (Peary Land, North Greenland). Bulletin of the Geological Society of Denmark 30, 11-36.

Hallam, A. 1969: Faunal realms and facies in the Jurassic. Palaeontology 12, 1-18.

Hallam, A. 1971: Provinciality in the Jurassic faunas in relation to facies and palaeogeography. In: Middlemiss, F.A., Rawson, P.F. \& Newall, G. (eds): Faunal provinces in space and time. Geological Journal Special Issue 4, 129-152.

Hallam, A. (ed.) 1973: Atlas of palaeogeography, 531 pp. Amsterdam: Elsevier.

Hallam, A. 1983: Early and mid-Jurassic molluscan biostratigraphy and the establishment of the Central Atlantic Seaway. Palaeogeography, Palaeoclimatology, Palaeoecology 43, 181-193.

Hallam, A. 1988: A reevaluation of Jurassic eustasy in the light of new data and the revised Exxon curve. In: Wilgus, C.K. et al. (eds): Sea-level changes - an integrated approach. Society of Economic Paleontologists and Mineralogists Special Publication 42, 261-273

Hallam, A. 1992a: Jurassic. In: Duff, P.McL.D. \& Smith, A.J. (eds): Geology of England and Wales, 325-354. London: Geological Society.

Hallam, A. 1992b: Phanerozoic sea-level changes, 266 pp. Perspectives in paleobiology and earth history series. New York: Columbia University Press.

Hamann, N.E. 1994: Den tektoniske udvikling af Rønne Graven - et seismisk studie, 136 pp. Unpublished Ph.D. thesis, University of Copenhagen, Denmark.

Hamblin, R.J.O., Crosby, A., Balson, P.S., Jones, S.M., Chadwick, R.A., Penn, I.E. \& Arthur, M.J. 1992: United Kingdom offshore regional report: the geology of the English Channel, 117 pp. London: Her Majesty's Stationery Office for the British Geological Survey.

Hancock, N.J. \& Fisher, M.J. 1981: Middle Jurassic North Sea deltas with particular reference to Yorkshire. In: Illing, L.V. \& Hobson, G.D. (eds): Petroleum geology of the continental shelf of North-West Europe: proceedings of the 2nd conference, 186-195. London: Heyden \& Son Ltd.

Haq, B.U., Hardenbol, J. \& Vail, P.R. 1987: Chronology of fluctuating sea levels since the Triassic. Science 235, 1156-1167.

Hedberg, H.D. (ed.) 1976: International stratigraphic guide: a guide to stratigraphic classification, terminology and procedure, 200 pp. New York: John Wiley \& Sons.

Helby, R., Morgan, R. \& Partridge, A.D. 1987: A palynological zonation of the Australian Mesozoic. In: Jell, P.A. (ed.): Studies in Australian Mesozoic palynology. Association of Australian Palaeontologists Memoir 4, 1-95.

Herngreen, G.F.W. \& de Boer, K.F. 1978: Dinoflagellate zonation of Upper Dogger and ?lowermost Malm in the Netherlands. Palínologia, número extraordinario 1, 283-291.

Horibe, Y. \& Oba, T. 1972: Temperature scales of aragonite-water and calcite-water systems. Fossils 23-24, 69-79 (in Japanese).

Imlay, R.W. 1980: Jurassic paleobiogeography of the conterminous United States in its continental setting. U.S. Geological Survey Professional Paper 1062, 134 pp.

Israelson, C., Buchardt, B., Funder, S. \& Hubberten, H.W. 1994: Oxygen and carbon isotope composition of Quaternary bivalve 
shells as a water mass indicator: last interglacial and Holocene, East Greenland. Palaeogeography, Palaeoclimatology, Palaeoecology 111, 119-134.

Japsen, P., Britze, P. \& Andersen, C. 2003: Upper Jurassic - Lower Cretaceous of the Danish Central Graben: structural framework and nomenclature. In: Ineson, J.R. \& Surlyk, F. (eds): The Jurassic of Denmark and Greenland. Geological Survey of Denmark and Greenland Bulletin 1, 233-246 (this volume).

Johnson, C.D. \& Hills, L.V. 1973: Microplankton zones of the Savik Formation (Jurassic), Axel Heiberg and Ellesmere Island, district of Franklin. Bulletin of Canadian Petroleum Geology 21, 178-218.

Jordan, R. \& Stahl, W. 1971: Isotopische PaläotemperaturBestimmungen an jurassichen Ammoniten und grundsätzlische Voraussetzungen für diese Methode. Geologisches Jahrbuch 89, 33-61.

Koppelhus, E.B. \& Nielsen, L.H. 1994: Palynostratigraphy and palaeoenvironments of the Lower to Middle Jurassic Baga Formation of Bornholm, Denmark. Palynology 18, 139-194.

Kunz, I. 1973: Sauerstoffisotopen - Temperaturmessungen an Jura-Sedimenten im Nordteil der DDR. Zeitschrift für Angewandte Geologie 19, 21-27.

Lam, K. \& Porter, R. 1977: The distribution of palynomorphs in the Jurassic rocks of the Brora outlier, northeast Scotland. Journal of the Geological Society (London) 134, 45-55.

Lentin, J.K. \& Williams, G.L. 1980: Dinoflagellate provincialism with emphasis on Campanian peridiniaceans. American Association of Stratigraphic Palynologists Contributions Series 7, $47 \mathrm{pp}$.

Longinelli, A. 1969: Oxygen-18 variations in belemnite guards. Earth and Planetary Science Letters 20, 337-340.

Lott, G.K., Thomas, J.E., Riding, J.B., Davey, R.J. \& Butler, N. 1989: Late Ryazanian black shales in the Southern North Sea Basin and their lithostratigraphical significance. Proceedings of the Yorkshire Geological Society 47, 321-324.

Michelsen, O. 1975: Lower Jurassic biostratigraphy and ostracods of the Danish Embayment. Danmarks Geologiske Undersøgelse II. Række 104, 287 pp.

Michelsen, O. 1978: Stratigraphy and distribution of Jurassic deposits in the Norwegian-Danish Basin. Danmarks Geologiske Undersøgelse Serie B 2, 28 pp.

Møller, J.J. 1986: Seismic structural mapping of the Middle and Upper Jurassic in the Danish Central Trough. Danmarks Geologiske Undersøgelse Serie A 13, 37 pp.

Mook, W.G. 1968: Geochemistry of the stable carbon and oxygen isotopes of natural waters in the Netherlands, 157 pp. Unpublished Ph.D. thesis, University of Groningen, Netherlands.

Morbey, S.J. \& Dunay, R.E. 1978: Early Jurassic to Late Triassic dinoflagellate cysts and miospores. In: Thusu, B. (ed.): Distribution of biostratigraphically diagnostic dinoflagellate cysts and miospores from the Northwest European continental shelf and adjacent areas. Continental Shelf Institute Publication 100, 47-59. (Institutt for Kontinentalsokkelundersøkelser (IKU), Trondheim, Norway).

Muir, M.D. \& Sarjeant, W.A.S. 1978: The palynology of the Langdale Beds (Middle Jurassic) of Yorkshire and its stratigraphic implications. Review of Palaeobotany and Palynology 25, 193-239.
Neves, R. \& Selley, R.C. 1975: A review of the Jurassic rocks of northeast Scotland. In: Finstad, K.G. \& Selley, R.C. (coordinators): Jurassic Northern North Sea Symposium, Stavanger, 28-30 September, 1975. Norwegian Petroleum Society (NPF) Proceedings JNNS/5, 1-29.

Nielsen, L.H. 2003: Late Triassic - Jurassic development of the Danish Basin and the Fennoscandian Border Zone, southern Scandinavia. In: Ineson, J.R. \& Surlyk, F. (eds): The Jurassic of Denmark and Greenland. Geological Survey of Denmark and Greenland Bulletin 1, 459-526 (this volume)

Nøhr-Hansen, H. 1986: Dinocyst stratigraphy of the Lower Kimmeridge Clay, Westbury, England. Bulletin of the Geological Society of Denmark 35, 31-51.

Norris, G. 1975: Provincialism of Callovian-Neocomian dinoflagellate cysts in northern and southern hemispheres. American Association of Stratigraphic Palynologists Contributions Series 4, 29-35.

Page, K.N. 2003: The Lower Jurassic of Europe: its subdivision and correlation. In: Ineson, J.R. \& Surlyk, F. (eds): The Jurassic of Denmark and Greenland. Geological Survey of Denmark and Greenland Bulletin 1, 23-59 (this volume).

Palmer, T.J. \& Jenkyns, H.C. 1975: A carbonate island barrier from the Great Oolite (Middle Jurassic) of central England. Sedimentology 22, 125-135.

Partington, M.A., Copestake, P., Mitchener, B.C. \& Underhill, J.R. 1993: Biostratigraphic calibration of genetic stratigraphic sequences in the Jurassic - lowermost Cretaceous (HettangianRyazanian) of the North Sea and adjacent areas. In: Parker, J.R. (ed.): Petroleum geology of Northwest Europe: proceedings of the 4th conference, 371-386. London: Geological Society.

Poulsen, N.E. 1984: Dinocyster fra Jura, Østgrønland. Biostratigrafi og dinocyst $\varnothing$ kologi af Hareelv Formation ( $\varnothing$ vre Jura), samt en gennemgang af dinocystøkologi i Jura, 123 pp. Unpublished M.Sc. thesis, University of Copenhagen, Denmark.

Poulsen, N.E. 1991: Upper Jurassic dinocyst stratigraphy in the Danish Central Trough. In: Michelsen, O. \& Frandsen, N. (eds): The Jurassic in the southern Central Trough. Danmarks Geologiske Undersøgelse Serie B 16, 7-15.

Poulsen, N.E. 1992: Jurassic dinoflagellate cyst biostratigraphy of the Danish Subbasin in relation to sequences in England and Poland; a preliminary review. Review of Palaeobotany and Palynology 75, 33-52.

Poulsen, N.E. 1993: Dinoflagellate cyst biostratigraphy of the Oxfordian and Kimmeridgian of Poland. Acta Geologica Polonica 43, 251-272.

Poulsen, N.E. 1994a: Dinoflagellate cyst biostratigraphy of Rhaetian-Ryazanian (uppermost Triassic - lowermost Cretaceous) deposits from the Danish Subbasin. Geobios 17, 409-414.

Poulsen, N.E. 1994b: Dinoflagellate cyst biostratigraphy of the Late Jurassic of Poland. Geobios 17, 401-407.

Poulsen, N.E. 1996: Dinoflagellate cysts from marine Jurassic deposits of Denmark and Poland. American Association of Stratigraphic Palynologists Contributions Series 31, 227 pp.

Poulsen, N.E. 1998: Upper Bajocian to Callovian (Jurassic) dinoflagellate cysts from central Poland. Acta Geologica Polonica 48, 237-245. 
Prauss, M. 1989: Dinozysten-Stratigraphie und Palynofazies im Oberen Lias und Dogger von NW-Deutschland. Palaeontographica B 214, 124 pp.

Rattey, R.P. \& Hayward, A.B. 1993: Sequence stratigraphy of a failed rift system: the Middle Jurassic to Early Cretaceous basin evolution of the Central and Northern North Sea. In: Parker, J.R. (ed.): Petroleum geology of Northwest Europe: proceedings of the 4th conference, 215-249. London: Geological Society.

Rawson, P.E. \& Riley, L.A. 1982: Latest Jurassic - Early Cretaceous events and the 'Late Cimmerian Unconformity' in the North Sea area. American Association of Petroleum Geologists Bulletin 66, 2628-2648.

Raynaud, J.F. 1978: Principaux dinoflagellés caractéristiques du Jurassique supérieur d'Europe du Nord. Palínologia, número extraordinario 1, 387-405.

Reid, R.E.H. 1973: Origin of the Mesozoic 'Boreal' Realm. Geological Magazine 110, 67-69.

Richards, P.C., Lott, G.K., Johnson, H., Knox, R.W.O'B. \& Riding, J.B. 1993: Jurassic of the Central and Northern North Sea. In: Knox, R.W.O'B. \& Cordey, W.G. (eds): Lithostratigraphic nomenclature of the UK North Sea 3, 219 pp. Nottingham: British Geological Survey.

Riding, J.B. 1982: Jurassic dinocysts from the Warboys Borehole, Cambridgeshire, England. Journal of Micropalaeontology 1, $13-18$.

Riding, J.B. 1984a: Dinoflagellate cyst range-top biostratigraphy of the uppermost Triassic to lowermost Cretaceous of northwest Europe. Palynology 8, 195-210.

Riding, J.B. 1984b: A palynological investigation of Toarcian to early Aalenian strata from the Blea Wyke area, Ravenscar, North Yorkshire. Proceedings of the Yorkshire Geological Society 45, 109-122.

Riding, J.B. 1987: Dinoflagellate cyst stratigraphy of the Nettleton Bottom Borehole (Jurassic: Hettangian to Kimmeridgian), Lincolnshire, England. Proceedings of the Yorkshire Geological Society 46, 231-266.

Riding, J.B. \& Ioannides, N.S. 1996: A review of Jurassic dinoflagellate cyst biostratigraphy and global provincialism. Bulletin de la Société géologique de France 167, 3-14.

Riding, J.B. \& Sarjeant, W.A.S. 1985: The role of dinoflagellate cysts in the biostratigraphical subdivision of the Jurassic System. Newsletters on Stratigraphy 14, 96-109.

Riding, J.B. \& Thomas, J.E. 1988: Dinoflagellate cyst stratigraphy of the Kimmeridge Clay (Upper Jurassic) from the Dorset coast, southern England. Palynology 12, 65-88.

Riding, J.B. \& Thomas, J.E. 1992: Dinoflagellate cysts of the Jurassic System. In: Powell, A.J. (ed.): A stratigraphic index of dinoflagellate cysts, 7-97. British Micropalaeontological Society Publication Series. London: Chapman \& Hall.

Riding, J.B. \& Thomas, J.E. 1997: Marine palynomorphs from the Staffin Bay and Staffin Shale formations (Middle-Upper Jurassic) of the Trotternish Peninsula, NW Skye. Scottish Journal of Geology 33, 59-74.

Riding, J.B., Penn, I.E. \& Woollam, R. 1985: Dinoflagellate cysts from the type area of the Bathonian Stage (Middle Jurassic; south-west England). Review of Palaeobotany and Palynology 45, 149-170.
Riding, J.B., Walton, W. \& Shaw, D. 1991: Toarcian to Bathonian (Jurassic) palynology of the Inner Hebrides, Northwest Scotland. Palynology 15, 115-179.

Riley, L.A. \& Fenton, J.P.G. 1982: A dinocyst zonation for the Callovian - middle Oxfordian succession of Northwest Europe. Palynology 6, 193-201.

Riley, L.A., Roberts, M.J. \& Connell, E.R. 1989: The application of palynology in the interpretation of Brae Formation stratigraphy and reservoir geology in the South Brae Field area, British North Sea. In: Collinson, J.D. (ed.): Correlation in hydrocarbon exploration, 339-356. London: Graham \& Trotman for the Norwegian Petroleum Society (NPF).

Salinas, I. 1984: Carbon and oxygen isotope variation in mollusc shells and the carbonate fraction of the Kimmeridge Clay of Westbury, England, 132 pp. Unpublished M.Sc. thesis, University of Copenhagen, Denmark.

Salvador, A. (ed.) 1994: International stratigraphic guide. A guide to stratigraphic classification, terminology, and procedure, 2nd edition, 214 pp. Boulder, Colorado: International Union of Geological Sciences and Geological Society of America, Inc.

Sarjeant, W.A.S. 1959: Microplankton from the Cornbrash of Yorkshire. Geological Magazine 96, 329-346.

Sarjeant, W.A.S. 1976: Dinoflagellate cysts and acritarchs from the Great Oolite Limestone (Jurassic: Bathonian) of Lincolnshire, England. Geobios 9, 4-45.

Sarjeant, W.A.S., Lacalli, T. \& Gaines, G. 1987: The cysts and skeletal elements of dinoflagellates: speculations on the ecological causes for their morphology and development. Micropaleontology 33, 1-36.

Sellwood, B.W. \& Hallam, A. 1974: Bathonian volcanicity and North Sea rifting. Nature 252, 275-304.

Shackleton, N.J. \& Kennett, J.P. 1975: Paleotemperature history of the Cenozoic and the initiation of Antarctic glaciation: oxygen and carbon isotope analyses in D.S.D.P. sites 277-279 and 281. Initial Reports of the Deep Sea Drilling Project $\mathbf{2 4}$, $743-755$.

Shaw, A.B. 1964: Time in stratigraphy, 365 pp. New York: McGraw Hill.

Smelror, M. 1993: Biogeography of Bathonian to Oxfordian (Jurassic) dinoflagellates: Arctic, NW Europe and circumMediterranean regions. Palaeogeography, Palaeoclimatology, Palaeoecology 102, 121-160.

Sorgenfrei, T. \& Buch, A. 1964: Deep tests in Denmark 1935-1959. Danmarks Geologiske Undersøgelse III. Række 36, 146 pp.

Spaeth, C., Hoefs, J. \& Vetter, U. 1971: Some aspects of isotopic composition of belemnites and related paleotemperatures. Geological Society of America Bulletin 82, 3139-3150.

Stahl, W. \& Jordan, R. 1969: General considerations on isotopic paleotemperature determinations and analyses on Jurassic ammonites. Earth and Planetary Sciences Letters 6, 173-178.

Stoker, M.S., Hitchen, K. \& Graham, C.C. 1993: United Kingdom offshore regional report: the geology of the Hebrides and West Shetland shelves, and adjacent deep-water areas, $158 \mathrm{pp}$. London: Her Majesty's Stationery Office for the British Geological Survey.

Stover, L.E. et al. 1996: Mesozoic-Tertiary dinoflagellates, acritarchs and prasinophytes. In: Jansonius, J. \& McGregor, D.C. (eds): 
Palynology: principles and applications, 641-750. Dallas: American Association of Stratigraphic Palynologists Foundation.

Sundsbø, G.O. \& Megson, J.B. 1993: Structural styles in the Danish Central Graben. In: Parker, J.R. (ed.): Petroleum geology of Northwest Europe: proceedings of the 4th conference, 1255-1267. London: Geological Society.

Surlyk, F., Callomon, J.H., Bromley, R.C. \& Birkelund, T. 1973: Stratigraphy of the Jurassic - Lower Cretaceous sediments of Jameson Land and Scoresby Land, East Greenland. Bulletin Grønlands Geologiske Undersøgelse 105, 76 pp.

Surlyk, F., Clemmensen, L.B. \& Larsen, H.C. 1981: Post-Palaeozoic evolution of the East Greenland continental margin. In: Kerr, J.W. \& Ferguson, A.J. (eds): Geology of the North Atlantic Borderlands. Canadian Society of Petroleum Geologists Memoir 7, 611-645.

Sykes, R.M. \& Callomon, J.H. 1979: The Amoeboceras zonation of the Boreal Upper Oxfordian. Palaeontology 22, 839-903.

Tan, F.C. \& Hudson, J.D. 1974: Isotopic studies on the palaeoecology and diagenesis of the Great Estuarine Series (Jurassic) of Scotland. Scottish Journal of Geology 10, 91-128.

Tan, F.C., Hudson, J.D. \& Keith, M.L. 1970: Jurassic (Callovian) paleotemperatures from Scotland. Earth and Planetary Science Letters 9, 421-426.

Tan, J.T. \& Hills, L.V. 1978: Oxfordian-Kimmeridgian dinoflagellate assemblages, Ringnes Formation, Arctic Canada. Geological Survey of Canada Paper 78-1C, 63-73.

Underhill, J.R. \& Partington, M.A. 1993: Jurassic thermal doming and deflation in the North Sea: implications of the sequence stratigraphic evidence. In: Parker, J.R. (ed.): Petroleum geology of Northwest Europe: proceedings of the 4th conference, 337-345. London: Geological Society.

Valdes, P.J. \& Sellwood, B.W. 1992: A palaeoclimate model for the Kimmeridgian. Palaeogeography, Palaeoclimatology, Palaeoecology 95, 47-72.

Valensi, L. 1953: Microfossiles des silex du Jurassique moyen. Remarques pétrographiques. Mémoire de la Société géologique de France 68, 100 pp.

Veizer, J. 1974: Chemical diagenesis of belemnite shells and possible consequences for paleotemperature determinations. Neues Jahrbuch für Geologie und Paläontologie, Abhandlungen 145, 279-305.

Veizer, J. \& Fritz, P. 1976: Possible control of post-depositional alteration in oxygen paleotemperature determinations. Earth and Planetary Science Letters 33, 255-260.

Vejbæk, O.V. \& Britze, P. (eds) 1994: Geological map of Denmark 1:750 000. Top pre-Zechstein (two-way traveltime and depth). Danmarks Geologiske Undersøgelse Kortserie 45, 8 pp., 6 maps.

Wall, D., Dale, B., Lohmann, G.P. \& Smith, W.K. 1977: The envi- ronmental and climatic distribution of dinoflagellate cysts in modern marine sediments from regions in the North and South Atlantic oceans and adjacent seas. Marine Micropaleontology 2, 121-200

Warrington, G., Cope, J.C.W. \& Ivimey-Cook, H.C. 1994: St. Audrie's Bay, Somerset, England: a candidate Global Stratotype Section and Point for the base of the Jurassic System. Geological Magazine 131, 191-200.

Whiteman, A.J., Rees, G., Naylor, D. \& Pegrum, R.M. 1975: North Sea troughs and plate tectonics. Norges Geologiske Undersøkelse Bulletin 316, 137-161.

Wierzbowski, A. 1989: Ammonite and stratigraphy of the Kimmeridgian at Wimanfjellet, Sassenfjorden, Spitsbergen. Acta Palaeontologica Polonica 34, 355-378.

Wierzbowski, A. \& Århus, N. 1990: Ammonite and dinoflagellate cyst succession of an upper Oxfordian - Kimmeridgian black shale core from the Nordkapp Basin, southern Barents Sea. Newsletters on Stratigraphy 22, 7-19.

Williams, G.L. \& Bujak, J.P. 1985: Mesozoic and Cenozoic dinoflagellates. In: Bolli, H.M., Saunders, J.B. \& Perch-Nielsen, K. (eds): Plankton stratigraphy, 847-964. Cambridge: Cambridge University Press.

Wimbledon, W.A. \& Cope, J.C.W. 1978: The ammonite faunas of the English Portland Beds and the zones of the Portlandian Stage. Journal of the Geological Society (London) 135, 183-190.

Woollam, R. 1980: Jurassic dinocysts from shallow marine deposits of the East Midlands, England. Journal of the University of Sheffield Geological Society 7, 243-261.

Woollam, R. 1982: Observations on the Jurassic dinocyst genera Energlynia and Wanaea. Journal of Micropalaeontology 1, $45-52$.

Woollam, R. \& Riding, J.B. 1983: Dinoflagellate cyst zonation of the English Jurassic. Institute of Geological Sciences Report 83/2, 44 pp.

Yükler, M.A. \& Speers, G.C. (in association with the Danish Modelling Group) 1988: Quantitative basin modelling in the Danish Central Trough. Section I, model description, concepts, input, and output parameters, 72 pp. Unpublished confidential report (in archives of Geological Survey of Denmark and Greenland, Copenhagen, Denmark).

Zeiss, A. 2003: The Upper Jurassic of Europe: its subdivision and correlation. In: Ineson, J.R. \& Surlyk F. (eds): The Jurassic of Denmark and Greenland. Geological Survey of Denmark and Greenland Bulletin 1, 75-114 (this volume).

Ziegler, P.A. 1988: Post-Hercynian plate reorganization in the Tethys and Arctic - North Atlantic domains. In: Manspeizer, W. (ed.): Triassic-Jurassic rifting; continental breakup and the origin of the Atlantic Ocean and passive margins. Developments in Geotectonics 22, 711-755. Amsterdam: Elsevier. 


\section{Appendix 1: Oxygen isotope palaeotemperatures from the Jurassic in Northwest Europe (by Bjørn Buchardt)}

The oxygen isotope palaeotemperature curve presented in Figure 6 of this paper was first constructed as part of a basin modelling project (B. Buchardt in: Yükler \& Speers 1988); note that the term palaeotemperature is used here to refer to the temperature registered by organisms living at the time of deposition (Epstein et al. 1951; Epstein \& Lowenstam 1953). The curve was compiled from previously published data, predominantly from older literature. The data reflect the state-of-the-art in isotope analyses in the 1960s and 1970s, at which time palaeotemperature studies were mainly based on macrofossils collected at outcrop. A brief description is given here of the principles behind, and the background of, the palaeotemperature curve.

An oxygen isotope palaeotemperature is a numerical value calculated from the oxygen isotopic composition of a carbonate shell according to the equations formulated by Epstein et al. (1951) and Craig (1965) for calcite and Horibe \& Oba (1972) for aragonite, and expressed in degrees Celsius $\left({ }^{\circ} \mathrm{C}\right)$. Interpretation of this value as a 'true' palaeotemperature is limited by several factors such as: (1) vital effects of the actual organisms (shell carbonate precipitated out of equilibrium with the surrounding water), (2) seasonal-selective shell formation, (3) variations in the oxygen isotope composition of the ambient water, and (4) postdepositional alteration of the shell. Of these factors, the last is deemed to be the most important.

Vital effects are well-known among large groups of calcareous-shelled organisms that should be avoided for palaeotemperature work. However, molluscs are known to exhibit vital effects to only a small degree (Epstein et al. 1951, Fritz \& Poplawski 1974, Buchardt \& Weiner 1988) and are eminently suitable for palaeotemperature studies. Among the molluscs, belemnites and ammonites are believed to have had a nektonic to nektobenthonic habitat, where seasonal variations in seawater temperatures probably were of less importance. They are therefore more suited for palaeotemperature work than, for example oysters, which lived closer to the coast, in waters probably affected by seasonality.

Calculation of isotopic palaeotemperatures presumes knowledge of isotopic compositions of both shell carbonate and ambient seawater. As the last parameter cannot be measured directly, indirect assessments are necessary. The world's oceans can be viewed as a homogeneous reservoir with a constant oxygen isotope composition in space, but not in time. The amount of ${ }^{18} \mathrm{O}$-depleted water bound in glacial ice affects the isotopic composition of the oceans globally. Oceans today have an oxygen isotope composition of $0 \%$ on the ä-scale relative to the SMOW standard (Standard Mean Ocean Water). During preglacial times, this value was lowered by at least $1 \% 0$ (Shackleton \& Kennett 1975), and consequently an average seawater $\ddot{a}^{18} \mathrm{O}$-value of $-1 \% 0$ has been applied in the present calculations. This correction amounts to a calculated temperature difference of approximately $4^{\circ} \mathrm{C}$ (Craig 1965). Unfortunately, seawater oxygen isotope homogeneity is also affected by any mixing with freshwater from rivers and streams discharging into the sea. River water is normally depleted in ${ }^{18} \mathrm{O}$ to a highly variable degree. Each estuary system thus has its own characteristic salinity $/ \ddot{a}^{18} \mathrm{O}$ relationship (Mook 1968; Israelson et al. 1994). During the Jurassic Period in Northwest Europe, palaeo-oceanographic conditions were complex, and local isotopic effects from river discharge were probably common (Salinas 1984; Nøhr-Hansen 1986). However, by mainly using nektobenthonic organisms such as belemnites and ammonites, these effects should be minimised.

Isotopic palaeotemperatures calculated from analyses of belemnites have been claimed by several authors to be unreliable (Longinelli 1969; Spaeth et al. 1971). This critique has focused on possible postdepositional alteration of belemnite guards (Stahl \& Jordan 1969; Spaeth et al. 1971; Veizer 1974). The controversy has never been resolved, and belemnite oxygen isotope palaeotemperatures should only be applied when the volume of belemnite data is large enough to allow cross-checks between different areas and lithologies.

Stahl \& Jordan (1969) pointed out that the metastable aragonite phase in fossils is more reliable for isotopic studies than calcite because recrystallization processes invariably lead to the modification of aragonite to calcite and therefore can easily be identified. Well-preserved aragonite in fossil shells can thus be taken as indication of minimal recrystallization and therefore of an unmodified isotopic signal. Therefore, aragonite from ammonites can be viewed as a more reliable source for oxygen isotope palaeotemperatures than calcite from belemnites. However, the number of Jurassic ammonite analyses reported in the literature are few, and it is not possible to compile a palaeotemperature curve solely from published ammonite data. Consequently, data from both belemnites and ammonites has been compiled, although belemnite data are excluded where differences in isotopic composition between ammonites and belemnites are significant.

Oxygen isotope data from Jurassic fossils in Northwest Europe (e.g. Britain, Germany and Poland) have been published by several authors (Bowen 1961a, b; Fritz 1964; Longinelli 1969; Stahl \& Jordan 1969; Tan et al. 1970; Jordan \& Stahl 1971; Kunz 1973; Tan \& Hudson 1974; Veizer 1974; Veizer \& Fritz 1976; Salinas 1984). These reports form the database for the oxygen isotope palaeotemperature curve presented in Figures 3-6 of this paper. Only data from ammonites and belemnites have been included. In most cases, stratigraphic resolution of the data is possible to zonal level. The curve is constructed from average values (solid line) and entire ranges (shaded area) of isotopic results for each stratigraphic 
level. In Table 2, the oxygen isotope palaeotemperatures have been calculated for each stage as an average and a range.

The isotope palaeotemperature curve as shown in Figures 3-6 is one method of displaying an oxygen isotope dataset for a heterogeneous selection of ammonites and belemnites from the Jurassic deposits of Northwest Europe. The fact that the calculated palaeotemperatures fall within a credible range $\left(8-26^{\circ} \mathrm{C}\right)$, supports the validity of the data and the compilation of information from different geographical areas. The only major discrepancy in the dataset is in the Callovian, where extremely low values (minimum $8^{\circ} \mathrm{C}$ ) in Germany and Poland (Jordan \& Stahl
1971; Kunz 1973) contrast with results from Scotland (maximum $25^{\circ} \mathrm{C}$; Tan et al. 1970). In this study, the Scottish results are excluded because they probably reflect the influence of ${ }^{18} \mathrm{O}$-depleted freshwater in a large estuarine system (Tan \& Hudson 1974).

The curve demonstrates isotopic variations which probably represent cold seawater conditions during the Pliensbachian and the Bajocian-Callovian in Northwest Europe. These cold intervals are in contrast to warmer seawater conditions during the Sinemurian, the Toarcian-Aalenian and the Oxfordian-Kimmeridgian. The maximum palaeotemperatures occurred at the Early-Middle Jurassic transition and during the Early Kimmeridgian. 